Cogné, N., Doepke, D., Chew, D., Stuart, F. M., and Mark, C. (2016) Measuring plume-related exhumation of the British Isles in Early Cenozoic times. Earth and Planetary Science Letters, 456, pp. 1-15.

(doi:10.1016/j.epsl.2016.09.053)

This is the author's final accepted version.

There may be differences between this version and the published version. You are advised to consult the publisher's version if you wish to cite from it.

http://eprints.gla.ac.uk/134604/

Deposited on: 31 January 2017

Enlighten - Research publications by members of the University of Glasgow http://eprints.gla.ac.uk 
4 列

\section{Measuring plume-related exhumation of the British Isles in Early Cenozoic}

times

Nathan Cogné ${ }^{1 *}$, Daniel Doepke ${ }^{1}$, David Chew $^{1}$, Finlay M. Stuart ${ }^{2}$ and Chris Mark ${ }^{1}$ ${ }^{1}$ Department of Geology, Trinity College Dublin, College Green, Dublin 2, Ireland. ${ }^{2}$ SUERC, Rankine Avenue, Scottish Enterprise Technology Park, East Kilbride G75 OQF, United Kingdom.

*Corresponding Author: cognen@tcd.ie

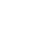

\section{Abstract}

Mantle plumes have been proposed to exert a first-order control on the morphology of Earth's surface. However, there is little consensus on the lifespan of the convectively supported topography. Here, we focus on the Cenozoic uplift and exhumation history of the British Isles. While uplift in the absence of major regional tectonic activity has long been documented, the causative mechanism is highly controversial, and direct exhumation estimates are hindered by the near-complete absence of onshore post-Cretaceous sediments (outside Northern Ireland) and the truncated stratigraphic record of many offshore basins. Two main hypotheses have been developed by previous studies: epeirogenic exhumation driven by the protoIceland plume, or multiple phases of Cenozoic compression driven by far-field stresses. Here, we present a new thermochronological dataset comprising 43 apatite fission track (AFT) and $102(\mathrm{U}-\mathrm{Th}-\mathrm{Sm}) / \mathrm{He}(\mathrm{AHe})$ dates from the onshore British Isles. Inverse modelling of vertical sample profiles allows us to define well-constrained regional cooling histories. Crucially, during the Paleocene, the thermal history models show that a rapid exhumation pulse (1-2.5 km) occurred, focussed on the Irish Sea. 
26 Exhumation is greatest in the north of the Irish Sea region, and decreases in intensity to the south and west. The spatial pattern of Paleocene exhumation is in agreement with the extent of magmatic underplating inferred from geophysical studies, and the timing of uplift and exhumation is synchronous with emplacement of the plumerelated British and Irish Paleogene Igneous Province (BIPIP). Prior to the Paleocene exhumation pulse, the Mesozoic onshore exhumation pulse is mainly linked to the uplift and erosion of the hinterland during the complex and long-lived rifting history of the neighbouring offshore basins. The extent of Neogene exhumation is difficult to constrain due to the poor sensitivity of the AHe and AFT systems at low temperatures. We conclude that the Cenozoic topographic evolution of the British Isles is the result of plume-driven uplift and exhumation, with inversion under compressive stress playing a secondary role.

Keywords: British Isles; exhumation; low temperature thermochronology; Early

Cenozoic; Iceland Plume

\section{Introduction}

It has long been proposed that mantle processes exert a first-order control on the Earth's topography (e.g. Cox, 1989). The topographic response to mantle upwelling can be either transient, with dynamically supported uplift and exhumation driven by mantle upwelling, or permanent, if driven by magmatic underplating (White and McKenzie, 1989). While the temperature anomaly associated with mantle plumes can propagate through the sub-lithospheric mantle over $1,000 \mathrm{~km}$ radially (White and McKenzie, 1989), the magnitude of induced uplift and exhumation can be 
51 hard to discriminate from intra-plate exhumation caused by horizontally-transmitted

52 far-field tectonic stresses (Burov and Cloetingh, 2009, Braun, 2010).

In this contribution we focus on the controversial question of whether a long-

recognised phase of post-Cretaceous exhumation in the British Isles was generated by upwelling mantle of the proto-Iceland plume (Davis et al., 2012), or by far-field tectonic stresses transmitted from the Alpine collision (Hillis et al., 2008). The Iceland plume is generally regarded as the source for Cenozoic anomalous magmatic activity and dynamic support throughout Greenland and the North Atlantic basin (e.g., Jones and White, 2003). This includes the British Paleogene Igneous Province (BIPIP), emplaced between ca. 63-58 Ma (Ganerød et al., 2010), which shows a clear protoIceland plume geochemical signature (Stuart et al., 2000). Thus the Irish Sea area encompassed the zone of influence of the plume in the early Paleogene times. At this time, important (i.e. kilometric scale) exhumation of the region took place (e.g., Rowley and White, 1998). However, as localised, poorly-dated inversion structures caused by compressive stresses are also reported in the British Isles throughout the Cenozoic era (e.g., Ziegler et al., 1995), the driving mechanism of the postCretaceous exhumation of the British Isles remains controversial (e.g., Hillis et al., 2008).

\section{Geological Context and Study Approach}

The post-Variscan evolution of Britain and Ireland and much of north-western Europe is characterized by orogenic collapse and prolonged extension, primarily in the Mesozoic times, which formed the basins of the Atlantic margin and the Irish and North Seas. Repeated episodes of exhumation are superimposed on these tectonic 
events, recorded by erosional unconformities in the Irish Sea basins, together with onshore and offshore AFT ages, vitrinite reflectance, sediment compaction studies and subsidence analyses (Rowley and White, 1998; Holford et al., 2005; Hillis et al., 2008). The Mesozoic exhumation episodes are variously attributed to either uplift induced by the dynamic support provided by mantle convection (Jones et al., 2012, and references therein) or to transmitted stresses from pre-existing, or incipient plate boundaries (Holford et al., 2005).

Determining the Cenozoic geological evolution of the British Isles is hindered by the paucity of Cenozoic onshore outcrops outside of Northern Ireland and the truncated stratigraphic record in many of the more accessible inboard basins. There is no consensus on the extent, magnitude, or timing of the Cenozoic event(s) (e.g. Hillis et al., 2008; Davis et al., 2012), for which two competing hypotheses have been proposed: (i) an epeirogenic mechanism linked to the proto-Iceland plume, either by Early Paleogene plume-related magmatic underplating or dynamic support (e.g. Brodie and White, 1994; Rowley and White, 1998; Jones et al., 2002) or (ii) basin inversion under compressive stress from the opening of the North Atlantic and the Alpine orogeny (e.g. Ziegler et al., 1995; Holford et al., 2005; Hillis et al., 2008).

The greatest magnitude of Cenozoic exhumation is generally reported around the Irish Sea region (Lewis et al., 1992; Al-Kindi et al., 2003), which is the focus of this study. The Irish Sea (including its southern extensions, the St George's Channel and Bristol Channel), and the Celtic Sea to the south, comprise a series of fully-filled, partially-inverted post-Variscan basins with little bathymetric expression, hosting late Carboniferous to Cenozoic sedimentary units (Rowley and White, 1998; Naylor and Shannon, 2009). Topographically, the Irish Sea is today merely a shallow (up to ca. $120 \mathrm{~m}$ ) marine embayment, which is likely related to ice-stream excavation and 
101 glacial palaeo-loading. The Celtic Sea basin preserves Jurassic and Cretaceous 102 successions, and in common with the North Sea and the Western Irish offshore 103 basins, these Mesozoic successions yield evidence for at least two episodes of 104 exhumation during Mid-Jurassic times and at the Jurassic / Cretaceous boundary 105 (Jones et al., 2012). However these episodes cannot be observed directly in the 106 north part of the Irish Sea basin system, as Mesozoic sedimentary rocks of post107 Early Jurassic age are generally absent (Naylor and Shannon, 2009), demonstrating 108 that a significant portion of the post-rift sequence is missing. Cenozoic sedimentary 109 rocks in the Irish Sea are only preserved locally in the St George's Channel Basin, 110 where $>1 \mathrm{~km}$ of Eocene-Oligocene sediments are preserved (Williams et al., 2005), 111 and in the Cardigan Bay Basin where a ca. $600 \mathrm{~m}$ thick sequence of Oligocene112 Miocene succession is reported (Naylor and Shannon, 2009). Cenozoic exhumation, 113 including partial basin exhumation, has therefore long been recognised in the Irish 114 Sea region (e.g. Kamerling, 1979).

$115 \quad$ Late Cretaceous chalk is present in the Ulster Basin in NE Ireland (Figure S1), 116 and underwent subaerial erosion prior to burial by the Paleocene Antrim Plateau 117 Basalts (Simms, 2009). Similar evidence for uplift and erosion in the Paleocene is 118 present in Mull and Morven in western Scotland (Figure S1). Outside of these 119 regions, the lack of onshore post-Variscan sedimentary rocks around the Irish Sea 120 basin system makes it difficult to infer the Mesozoic to Cenozoic geological evolution. 121 Several previous studies have utilised the apatite fission-track (AFT) low-temperature 122 thermochronometer (Lewis et al., 1992; Green et al., 1997; Green et al., 2000; Allen 123 at al., 2002; Green, 2002; Holford et al., 2005) to quantify and date exhumation. 124 However, the thermal sensitivity of the AFT system alone $\left(120-60^{\circ} \mathrm{C}\right.$; Donelick et al., 1252005 ) is not well suited to detect cooling from shallow crustal depths of $1-3 \mathrm{~km}$. 
126 Green et al. (2000) argued that Ireland has suffered repeated cycles of exhumation and reburial during the Mid-Jurassic, Early Cretaceous, Early Cenozoic and a final exhumation event during Neogene times. Allen et al. (2002) preferred a more continuous exhumation history with reburial restricted to the Late Cretaceous period

130 followed by rapid exhumation during the Cenozoic times. Using a combination of 131 apatite $(\mathrm{U}-\mathrm{Th}) / \mathrm{He}$ and AFT dating of vertical profiles from the western Irish onshore,

132 Cogné et al. (2014) showed that the Mesozoic exhumation history of western Ireland 133 was closely linked to the rifting history of the Atlantic margin basins to the west. The 134 Cenozoic history was poorly constrained, and an Early Cenozoic exhumation pulse 135 was not detected. AFT studies from the eastern side of the Irish Sea suggest that 136 exhumation of 2 to $3 \mathrm{~km}$ occurred during the Early Cenozoic epoch in NE England 137 (Lewis et al., 1992, Green et al., 1997, Green, 2002). This did not, apparently, extend 138 to North Wales (Holford et al., 2005), where the only reported exhumation event 139 occurred during the Triassic - Early Jurassic times. On a regional scale, however, 140 the outcrop pattern of post-Triassic sedimentary rocks in Britain strongly suggests 141 southeast-directed tilting during the Early Cenozoic (Cope, 1994), while the 142 provenance of heavy mineral assemblages in the Paleogene sands of the Hampshire 143 Basin suggests a source in Scotland (Morton, 1982), implying that that NW Britain 144 was being uplifted at that time.

145 The timing of onshore and offshore exhumation in the Irish Sea region thus 146 remains controversial, and the relative importance of Jurassic to Early Cretaceous 147 syn-rift versus Early Cenozoic to Neogene post-rift exhumation events remains 148 unclear (Rowley and White, 1998; Holford et al., 2005, Hillis et al., 2008, Davis et al., 149 2012). In this study, we combine the AFT system with the apatite (U-Th-Sm)/He $150(\mathrm{AHe})$ technique, which is sensitive to temperatures between $110^{\circ} \mathrm{C}$ and $40^{\circ} \mathrm{C}$ 
151 (Shuster and Farley, 2009) to yield better-constrained thermal history models on the

152 onshore part of Britain and Ireland. Crucially, we also employ a pseudo-vertical

153 profile sampling approach (i.e. summit-to-valley transects) that significantly

154 strengthens the models as they have to respect data constraints from multiple

155 samples, which results in significantly smaller uncertainties than modelling samples

156 independently (Gallagher et al., 2005). Combining the AFT and AHe systems with

157 inverse modelling of vertical sample profiles therefore allows us to define the cooling

158 history of the Irish Sea region by constraining small magnitude exhumation phases

159 (ca. $1 \mathrm{~km}$ ), which conventional approaches (such as modelling of fission-track data

160 from individual samples) could fail to detect.

\section{Thermochronology}

\subsection{Sampling strategy}

We favoured a pseudo-vertical profile sampling approach (i.e., summit-tovalley sample transects) wherever permitted by lithology and topography. However in

167 some areas (mainly northeast Ireland and the Southern Uplands in Scotland) we employed single samples that were modelled individually. In total seven vertical profiles were sampled; four in Ireland, two in Wales and one from the Paleocene Isle of Arran Northern Granite (Fig. 1). Three samples were collected from the Isle of

171 Man, including two from the same profile but with a small vertical offset. Importantly,

172 one sample from northeast Ireland was taken from a borehole with a present-day 173 depth of $1702 \mathrm{~m}$ below surface. In total, we obtained 43 AFT ages and 102 (U-Th$174 \mathrm{Sm}) / \mathrm{He}$ individual ages. 


\subsection{Fission track analyses}

The detailed apatite fission track methodology is described in the supplementary material. All samples were prepared and analysed in Trinity College Dublin (TCD) using the etching protocol of Donelick et al. (2005). Uranium concentration measurements for fission track dating were undertaken by LA-ICPMS at TCD following the protocols described in Donelick et al. (2005) and Cogné et al. (2014). Apatite U-Pb age data were also obtained from the same LA-ICPMS spot ablations with data reduction procedures following Chew et al. (2014). U-Pb data were only acquired for use as high temperature constraints for the modelling procedure (see thermal history modelling methodology section below) and are not presented here as they do not impact on the interpretations of the Mesozoic Cenozoic thermal histories.

\section{$3.3(U-T h-S m) / H e$}

A full description of the $(\mathrm{U}-\mathrm{Th}-\mathrm{Sm}) / \mathrm{He}$ methodology is provided in the supplementary material. All apatite grains were picked in TCD, and all (U-Th-Sm)/He measurements were carried out at the Scottish Universities Environmental Research Centre (SUERC). All procedures are described in detail in Foeken et al. (2006). The minimum uncertainty on the calculated ages of the apatite unknowns is fixed at $8 \%$ based on repeated (U-Th-Sm)/He measurements of the Durango apatite standard.

\section{Results}

For surface samples (excluding the Paleocene Isle of Arran Northern Granite), the AFT ages range from $60.4 \pm 4.0 \mathrm{Ma}$ to $299.2 \pm 27.6 \mathrm{Ma}$ (all AFT age 
201 uncertainties in this study are reported at the $2 \sigma$ level; Table 1 ; Fig. 2). The mean

202 track length (MTL) ranges from $12.5 \pm 0.25 \mu \mathrm{m}$ to $13.9 \pm 0.22 \mu \mathrm{m}$ (1 SE) with

203 standard deviations between $1.06 \mu \mathrm{m}$ and $1.82 \mu \mathrm{m}$. The kinetic parameter $\left(D_{\text {par; }}\right.$; e.g.,

204 Donelick et al., 2005) is relatively small for all samples, ranging from 1.52 to $2.1 \mu \mathrm{m}$,

205 similar to Durango apatite (mean $D_{\text {par }}$ measured for the same etching protocol is 1.66

$206 \mu \mathrm{m})$. The Ire-10 and Isle of Arran samples exhibit Early Cenozoic AFT ages, which

207 are explained by the present-day temperature of the Ire-10 sample (collected $1702 \mathrm{~m}$

208 below the surface), and the Paleocene emplacement age of the Isle of Arran

209 Northern Granite. Excluding these samples, only two samples yield Late

210 Cretaceous/Early Cenozoic AFT ages, and they are located on the Isle of Man (loM-

2113 ) and the Southern Uplands (Sct-1). The rest of the samples show a large spread in

212 AFT age from the Permian to the Early Cretaceous.

213 The $F_{\mathrm{T}}$-corrected $\mathrm{AHe}$ ages of the surface samples range from $42.7 \pm 3.4 \mathrm{Ma}$

214 to $248.6 \pm 19.9 \mathrm{Ma}$ (all AHe age uncertainties are reported at the $1 \sigma$ level; Table 2,

215 Fig. 2). The borehole sample (Ire-10) yielded younger $\mathrm{AHe}$ ages due to its higher

216 present-day temperature. In contrast to the AFT ages, many samples from around

217 the Irish Sea exhibit Late Cretaceous/Early Cenozoic AHe cooling ages (Fig. 2).

218 Some grains yield older $F_{\mathrm{T}}$-corrected ages than their corresponding AFT age. The

219 amount of $\alpha$-recoil damage within the apatite crystal lattice has a strong influence on

220 the effective closure temperature of the AHe system (e.g. Green et al. 2006, Shuster

221 and Farley 2009), which can be approximated by the effective uranium (eU) factor

222 where eU $=[\mathrm{U}]+0.24$ [Th] (Green et al., 2006). In our dataset, the eU factor and

$223 \mathrm{AHe}$ age are only weakly correlated, but most of the He aliquots that yield older $\mathrm{AHe}$

224 ages than the corresponding AFT age exhibit relatively high eU values. For these 
225 aliquots, the effective closure temperature for the AHe system could be higher than

226 that of the AFT system which would thus explain the old AHe ages.

\section{Thermal history modelling methodology}

Inverse modelling of the AHe and AFT (track length and age) data was undertaken to extract thermal history information. We used the QTQt software of Gallagher (2012), which employs a Bayesian trans-dimensional Markov Chain Monte Carlo (MCMC) approach. The modelling procedure is described in detail in Gallagher 234 (2012).

In this study, a general time-temperature box with a temperature range of $75 \pm$ $75^{\circ} \mathrm{C}$ (which spans the upper-temperature sensitivity limit of the AFT system to the present-day surface temperature) and a time range (which spans from the present day back to a sample-specific starting point) is used as the parameter space. A series of discrete time-temperature points are sampled within this time-temperature space to construct a continuous thermal history, and the data likelihood is then 241 calculated for that model. To model the fission track data, we used the individual 242 track count data, the length and angle to the c-axis of confined tracks, the annealing 243 model of Ketcham et al. (2007) and the likelihood function of Gallagher (1995). The 244 measured AHe ages were modelled using a spherical diffusion formulation which 245 simulates both $\alpha$-ejection and diffusion during the evolution of the thermal history 246 (Meesters and Dunai, 2002), combined with the radiation damage model of Flowers 247 et al. (2009). Additionally, the eU parameter is allowed to vary by up to $25 \%$ to take 248 into account uncertainties on the apatite grain-size measurements, deviation from an 249 ideal euhedral shape, and possible minor zonation of parent nuclides. 
The present-day surface temperature for the sample is dependent on the

251 sample elevation, and is typically set at between $15 \pm 5^{\circ} \mathrm{C}$ and $5 \pm 5^{\circ} \mathrm{C}$. For the

252 vertical profiles, the present-day offset between the top and bottom sample is set at 8

$253 \pm 3^{\circ} \mathrm{C} / \mathrm{km}$ to take into account the change of surface temperature with elevation. We

254 also employed independent geological evidence for the starting time-temperate

255 constraint for each model, such as either the depositional age of the sample, the

256 timing of the last regional metamorphic event experienced by the sample, or the 257 sample U-Pb apatite age as determined by LA-ICPMS. The number of iterations 258 depends on the stability of the likelihood chain (see Gallagher, 2012 for details), but 259 was always set at a minimum of 200,000 iterations for single samples and at 400,000 260 iterations for vertical profiles.

261 Expected models are presented. They are essentially a weighted-mean model, 262 while credible intervals (the Bayesian equivalent of confidence intervals) were 263 calculated using the ensemble of thermal history solutions. These credible intervals 264 represent the range of the model parameters contained in the posterior distribution at 265 the specified level of probability (i.e., 95\%).

266 In addition to the inverse modelling, forward modelling has been undertaken 267 for some samples to test whether we could extract more information than provided by 268 the inverse models. All the predictions (i.e., modelled versus observed ages or track269 length distributions) associated with the presented models are provided in the 270 supplementary material.

\section{Synthesis of the thermal history models}


A detailed description of the thermal history models including the high-

275 temperature constraints, the geometry of the cooling/reheating path and the timing of cooling/reheating pulses is provided in the Supplementary Materials, and forms the basis of the synthesis of the thermal history models described below.

\subsection{Late Paleozoic and Mesozoic thermal history}

The models indicate that all the profiles in Palaeozoic rocks (i.e., excluding the

Paleocene Isle of Arran Northern Granite) underwent rapid cooling following the last significant regional high-temperature event (the Variscan or Caledonian orogenies) and had entered the apatite PAZ by the beginning of the Mesozoic era. The thermal

284 histories modelled from the single samples have larger uncertainties and do not 285 contradict the cooling histories from the profiles. All the Palaeozoic samples had entered the apatite PAZ by the beginning of Mesozoic times.

A discrete pulse of Mesozoic cooling is evident in almost all profiles, while the thermal histories for individual samples can still accommodate such a cooling phase although it is poorly constrained due to the larger confidence intervals on these 290 models. In Wales, the first recognised period of cooling occurred in North Snowdonia 291 (Fig. 3a) and Pembrokeshire (Fig. 3b) during Permo-Triassic times. In North Wales 292 this is coeval with an important rifting episode in the East Irish Sea Basin and in the 293 Cheshire Basin (Rowley and White, 1998). In Anglesey, the Mesozoic cooling 294 episode occurred later during Early to Middle Jurassic times (Fig. 3b), which is 295 contemporaneous with an important phase of rifting and clastic sediment deposition 296 in the Cardigan Bay Basin (Naylor and Shannon 2009). This history is similar to that 297 depicted by Holford et al. (2005) for NW Wales. In South Wales, the first cooling 298 episode recognised in Pembrokeshire is contemporaneous with the Permo-Triassic 
opening of the Bristol Channel to the south (Kamerling, 1979), and with the opening

300 of the St George's Channel Basin to the north during Triassic times (Welch and 301 Turner, 2000). Further east, the large end-Triassic cooling pulse in the Brecon 302 Beacons (Fig. 3c) is synchronous with the onset of the main phase of deposition in 303 the East Bristol Channel Basin (Kamerling, 1979). In southern Ireland, the Galtee Mountains (Fig. 4a) and Mount Leinster (Fig. 4b) profiles show an important phase of cooling during the Early Jurassic period, similar to the episode recognised by Green et al. (2000). This is compatible with a thick Triassic to Early Jurassic sedimentary sequence in the North Celtic Sea Basin to the south, and with a major rifting episode in the Central Irish Sea Basin to the southeast (Naylor and Shannon 2009). The Slieve Bloom profile in central Ireland (Fig. 4c) shows a rather limited phase of Mesozoic cooling compared to all other 311 profiles examined in this study, with a minor acceleration in cooling rate around the Jurassic-Cretaceous boundary at ca. $145 \mathrm{Ma}$. This is coeval with the cooling episode 313 recognised by Cogné et al. (2014) in vertical profiles from the western Ireland 314 onshore but is of smaller magnitude. The Lugnaquilla profile (Fig. 4d) records a pulse 315 of cooling towards the end of the Early Cretaceous period at $110 \mathrm{Ma}$, similar to the 316 cooling pulse detected in the forward model from the Isle of Man profile (Fig. 5a). 317 This Early Cretaceous cooling episode has been widely detected in Central and East 318 Irish Sea basins (Holford et al., 2005) as well as onshore Ireland (Green et al., 2000). The timing and spatial distribution of Mesozoic cooling in Ireland and western 320 Britain is thus complex and lasted over $150 \mathrm{Ma}$. It has been argued that two 321 Mesozoic exhumation episodes occurred in the vicinity of the British Isles during Mid322 Jurassic (ca. $175 \mathrm{Ma}$ ) and Early Cretaceous (ca. $140 \mathrm{Ma}$ ) times, due to the presence 323 of large swells that induced the development of dynamic topography over a large 
324 region (e.g. Jones et al., 2012). However, our data seems to indicate that the

325 Mesozoic cooling episodes recorded by our samples have a more local spatial 326 extent, as they occurred at different times during the Mesozoic over a distance of 327 only few tens to one hundred kilometres. While a convectively-supported exhumation 328 mechanism can explain a component of the Mesozoic exhumation, localised uplift 329 induced by the flexural response to extension over 50 to $100 \mathrm{~km}$ length scales, would 330 explain how each profile records a localised and different cooling history. Therefore 331 we link the late Permian to Jurassic cooling episodes primarily to the complex rifting 332 history of the basins and sub-basins in the Irish Sea and Celtic Sea. Each region 333 appears to have experienced cooling that is synchronous with the deposition of syn334 rift sediments in the closest offshore basins. The Slieve Bloom profile is the furthest 335 from the coast and is the only profile that does not show an important cooling 336 episode during the Mesozoic era, showing that the flexural response diminishes 337 rapidly away from the offshore basins, in accordance with the low elastic thickness of 338 the British Isles' lithosphere (Tiley et al., 2003). Thus cooling is likely to be mainly 339 linked to rift-related uplift and subsequent erosion of the hinterland during the 340 extensional episodes that formed the different sub-basins of the Irish Sea basin 341 system. However the Bayesian modelling approach employed in this study tends to 342 favour simpler solutions (see Gallagher, 2012), and thus might not be able to 343 discriminate between discrete episodes of cooling that are close together in time. 344 Assuming a palaeogeothermal gradient of $25^{\circ} \mathrm{C} / \mathrm{km}$ similar to the present day 345 (Goodman et al., 2004, Downing and Gray, 1986), the total amount of Mesozoic rift346 related exhumation ranged between 1.5 and $3 \mathrm{~km}$ in the studied profiles.

347 While the onshore Mesozoic exhumation pulse can be linked to rifting in the 348 closest offshore basins for most of the profiles, the onshore Early Cretaceous 
exhumation phase seen in the Lugnaquilla and Isle of Man profiles does not have a

350 corresponding rifting episode in the Irish Sea basin system. On the contrary, low351 temperature thermochronology data for the East Irish Sea Basin and Central Irish

352 Sea Basin suggest that the Early Cretaceous was associated with a phase of 353 exhumation (Holford et al., 2005), while at this time there is no recorded deposition in 354 the North St George's Channel Basin (Welch and Turner 2000) and in the Kish Bank 355 Basin (Naylor and Shannon, 2009). Therefore, the Early Cretaceous exhumation is 356 likely to be more regional in extent than the previous Mesozoic exhumation episodes 357 described above and is likely linked to swell-related dynamically support as proposed 358 by Jones et al. (2012). However the amount of uplift generated may be minor, as it is 359 not seen in other profiles in Ireland or Wales. Alternatively, Holford et al. (2005), 360 amongst others, argue that this episode may reflect uplift due to a period of 361 significant extension of the Atlantic Margin and the onset of seafloor spreading in the 362 Bay of Biscay and in the Goban Spur. However this explanation implies a very strong 363 lithosphere, in contradiction to the results of Tiley et al. (2003). Our results cannot 364 readily decipher between these two competing hypotheses.

\subsection{Cenozoic thermal history}

A second major phase of post-Variscan cooling has occurred in the Early 368 Cenozoic period. The Isle of Arran profile in SW Scotland (Fig. 5b) shows that this 369 Paleocene intrusion achieved surface temperatures shortly after emplacement. This 370 cooling pulse is also evident in individual samples in the Southern Uplands (Fig. 6a) 371 and in northeast Ireland (Fig. 6b). The cooling phase is also detected in the Isle of 372 Man and Snowdonia profiles (Fig. 5a and 3a), and can be detected in individual 373 samples from Anglesey and Pembrokeshire in forward models (Fig. 3b). The two 
374 profiles from the Leinster granite (Mount Leinster, Fig. 4b; Lugnaquilla, Fig. 4d) do

375 not show a well-defined rapid pulse of Early Cenozoic cooling, but importantly cooling 376 in both profiles initiated at ca. $60 \mathrm{Ma}$. This is significantly earlier than the onset of 377 post-Mesozoic cooling in southern Ireland (Galtee Mountains, Fig. 4a), central Ireland 378 (Slieve Bloom; Fig. 4c) and in western Ireland (Cogné et al., 2014), which typically 379 commenced in Neogene times. Therefore this episode of Early Cenozoic cooling is restricted to the margins of the Irish Sea. It starts between ca. 65 and $60 \mathrm{Ma}$ and 381 lasts for ca. 10Ma.

We stress here that it is the use of two thermochronometers coupled with a vertical profile approach that allowed us to demonstrate the regional extent of this 384 cooling episode. As shown on Figure 7, the use of AFT data alone for the vertical 385 profile model (Fig. 7b) or modelling individual samples using combined AFT and AHe data (Fig. 7c and 7d) would not detect portions of the cooling history in the studied area. Using two thermochronometers with a vertical profile approach (Fig.7a) not only allowed us to detect this cooling episode, but also to show that it progressively decreases in intensity from north to south and to the west as discussed below.

\subsection{Spatial distribution of Early Cenozoic cooling}

The sampling density in this study does not allow for the construction of a 393 detailed Early Cenozoic cooling map, primarily because analysing multiple samples 394 in a single profile is significantly more time consuming, limiting the spatial density of 395 the resulting data. However, the behaviour of samples in the inverse modelling process can also provide an indication of the intensity of Early Cenozoic cooling, as an Early Cenozoic cooling episode has to be significant to be detected in single

398 samples given that the inversion modelling approach favours simpler solutions. 
We can delimit four different areas (Fig. 8) based on the modelled behaviour

400 of single samples and vertical profiles. (i) A significant pulse of Early Cenozoic 401 cooling is present when it is detected by inverse modelling on single samples, and 402 this area runs from the Southern Uplands in SW Scotland to northeast Ireland (red 403 stars on Fig. 8) It also encompasses the prominent cooling pulse detected on the Isle 404 of Arran, but it should be noted that we have not collected a sample from this region 405 outside of the aureole of this Paleocene intrusion. (ii) The second region comprises west Wales and the Isle of Man (orange stars on Fig. 8), where inverse modelling of

407 individual samples does not show the pulse of Early Cenozoic cooling (or is not well 408 constrained as in sample $\mathrm{Pb}-1$ from Pembrokeshire) but where it is detected by 409 inverse modelling of vertical profiles (e.g. the Snowdonia profile). (iii) A third zone in 410 southeast Ireland (yellow stars on Fig. 8) is characterized by vertical profiles that do 411 not show a discrete, rapid pulse of Early Cenozoic cooling, but slow cooling 412 nevertheless initiated at ca. $60 \mathrm{Ma}$. (iv) The final zone comprises the three profiles in 413 this study (Brecon Beacons, Slieve Bloom and Galtee Mountains) and the five 414 profiles from the western Irish onshore (Cogné et al., 2014) that do not show cooling 415 during the Early Cenozoic (blue stars on Fig. 8).

\section{Discussion}

\subsection{Linking Early Cenozoic cooling to exhumation}

We associate the pulse of enhanced Early Cenozoic cooling described above with a pronounced phase of exhumation that has been previously detected in the

422 Irish Sea basin system (e.g., Rowley and White, 1998; Holford et al., 2005). 423 Assuming a paleogeothermal gradient of $25^{\circ} \mathrm{C} / \mathrm{km}$, similar to the present-day 
424 (Goodman et al., 2004, Downing and Gray, 1986), Early Cenozoic exhumation of ca.

$4252 \mathrm{~km}$ is indicated in the three samples from northeast Ireland, and sample Sct-2 in

426 the NW Southern Uplands (Fig. 8). Early Cenozoic exhumation is most significant in

427 sample Sct-1 (ca. $3 \mathrm{~km}$ ). This sample is also the only surface sample (excluding the

428 Paleocene Isle of Arran Northern Granite) that yields an Early Cenozoic AFT age in

429 our dataset, indicating that the Early Cenozoic thermal event is more significant in the

430 southwest part of the Southern Uplands than elsewhere in the studied area. Such

431 young AFT ages are relatively uncommon for surface samples in Britain and Ireland,

432 and they tend to be clustered around the NE Irish Sea (e.g. the Vale of Eden, Lewis

433 et al., 1992; Lake District, Green, 2002, East Irish Sea Basin, Lewis et al., 1992;

434 Green et al., 1997). Early studies around the East Irish Sea Basin argued for

435 exhumation of up to $3 \mathrm{~km}$ (e.g. Lewis et al., 1992), similar to the exhumation signal

436 we infer for sample Sct-1. However others (e.g. Green et al., 1997) have

437 subsequently argued that the peak temperatures recorded by such samples resulted

438 from a high geothermal gradient. The subsequent cooling history would then only be

439 partly associated with Early Cenozoic exhumation, as there is also a cooling

440 component associated with thermal relaxation from an initial high Early Cenozoic

441 heat flow. Therefore the total amount of denudation is somewhat unclear, but 2.5 to 3

$442 \mathrm{~km}$ is within the upper limits of previously published exhumation estimates for the

443 East Irish Sea Basin (Rowley and White, 1998). On the other side of the East Irish

444 Sea Basin, the exhumation inferred for the Isle of Man is lower, at ca. $1.5 \mathrm{~km}$.

445 The amount of Early Cenozoic exhumation for the Paleocene Isle of Arran

446 Northern Granite is difficult to estimate from low-temperature thermochronology

447 alone, as it cooled rapidly from magmatic temperatures following emplacement.

448 However, maximum exhumation cannot exceed emplacement depth estimates of 2-3 
449 km (England, 1992); our data indicate cooling and exhumation was complete by the

450 Early Eocene. Further south in Wales, the amount of Early Cenozoic exhumation is 451 estimated at 1.5 to $2 \mathrm{~km}$ based on the cooling histories of the Snowdonia profile and 452 the Anglesey and Pembrokeshire samples. Finally in southeast Ireland, Early 453 Cenozoic exhumation cannot exceed ca. $1-1.5 \mathrm{~km}$, but it is harder to estimate as the 454 Early Cenozoic cooling history is not represented by a discrete cooling pulse.

455

\subsection{Causal mechanisms for Early Cenozoic exhumation}

Several authors have argued for Cenozoic exhumation caused by localised inversion due to far-field tectonic stress transmission (e.g., Hillis et al., 2008; Holford et al., 2005), but this mechanism is unlikely to be the primary cause for the Early Cenozoic exhumation pattern we document here. The onshore pattern of Early Cenozoic exhumation is not spatially associated with any major faults nor is it limited to belts of known compressive tectonism (Fig. 8). This is not to say that a localised structural control on exhumation is not present; for example, it is required to explain the close spatial proximity (ca. $15 \mathrm{~km}$ ) of the Late Paleocene Mourne Mountains granite and the Early Paleocene Antrim basalts at similar elevations. However, uplift and exhumation is clearly centred around the Irish Sea, with the maximum amount of exhumation in the north sector (SW Scotland and northeast Ireland) and decreasing towards the south. Moreover, even though Cenozoic crustal shortening is well documented in the southern British Isles, only a subset of this shortening can be attributed to Early Cenozoic movements (Welch and Turner, 2000; Blundell, 2002). Total shortening is an order of magnitude too small to account for the observed exhumation of between 1 to $3 \mathrm{~km}$ (Davis et al., 2012). Additionally, if exhumation was controlled by far-field compression then partitioning of shortening onto discrete, brittle 
474 crustal structures is expected, together with the formation of structurally-controlled

475 sediment traps hosting Early Cenozoic strata in zones where Early Cenozoic 476 exhumation was minimal to absent. However, the oldest known Cenozoic 477 sedimentary rocks in the Irish Sea basin system comprise the minor Eocene 478 succession in the St George's Channel Basin (Welch and Turner, 2000). Late 479 Cretaceous and Early Paleogene sedimentary rocks are entirely absent in the region, 480 which requires regional-scale exhumation of the entire Irish Sea region during the 481 Early Cenozoic period.

Therefore, although structural inversion under compressive stress may have 483 played a secondary role in the observed pattern of Early Cenozoic exhumation, our 484 data demonstrate that this exhumation in and around the Irish Sea region is primarily 485 due to epeirogenic causes. The emplacement of the British-Irish Paleogene Intrusive Province (BIPIP) has been linked to the thermal effects of the proto-Iceland Plume. The BIPIP ranges in age from ca. 63 to $58 \mathrm{Ma}$ (Ganerød et al., 2010) and comprises a series of extrusive and intrusive centres that run from the Outer Hebrides in NW Scotland through the Irish Sea as far south as Lundy (Fig. 8). The Early Cenozoic 490 exhumation pulse thus coincides temporally and spatially with this intense phase of magmatic activity that shortly predates the opening of the North Atlantic at ca. $55 \mathrm{Ma}$

492 (Rickers et al., 2013). Furthermore, Persano et al. (2007) have argued for a similar 493 episode of Early Cenozoic uplift and exhumation associated with the proto-Iceland 494 plume in western Scotland, while regional-scale Paleocene uplift of northwest Britain 495 and the resultant southeast-directed tilting is in accordance with the outcrop pattern 496 of post-Triassic sedimentary rocks in Britain (Cope, 1994, Fig. 8) and with the 497 provenance of Early Cenozoic sedimentary rocks in the Hampshire basin (Morton, 498 1982). Regional-scale uplift is also in accordance with stratigraphic evidence for large 
clastic fan bodies during Paleocene and Eocene times on the margins of the uplifted

500 area (White and Lovell, 1997; Jones et al., 2002; Jones and White, 2003).

501

Brodie and White (1994) proposed that ca. $5 \mathrm{~km}$ of Paleocene magmatic

502

503

underplating occurred at the base of the crust underlying the Irish Sea region contemporaneous with the emplacement of the BIPIP, which induced sufficient uplift

504 to create regional-scale Paleocene exhumation. Using a wide-angle seismic profile

505 that crossed the Irish Sea, Al-Kindi et al. (2003) imaged an 8 km-thick high velocity

506 zone at the base of the crust underneath the eastern Irish Sea, and which they too

507 interpreted as underplated magmatic material. Tomlinson et al. (2006) refined the

508 shape of this body using seismic receiver function data and their calculated thickness

509 variations are a good match with the spatial distribution of exhumation detected in

510 this study (Fig. 8), and Davis et al. (2012) also argued for the presence of such a

511 high-velocity body beneath Scotland and extending southwards. It is also possible

512 that a component of the observed exhumation pulse was associated with transient

513 and intermittent dynamic uplift induced by the presence of a hot vertical convective

514 sheet in the upper asthenospheric mantle - the presumed source of the underplated

515 material - which would explain the pulsed record of deep-water clastic fans in the

516 Early Cenozoic offshore basins around the British Isles (White and Lovell, 1997,

517 Jones et al., 2002). Following the emplacement of the BIPIP, a second phase of

518 transient uplift that encompassed a large part of the British Isles occurred at the

519 Paleocene / Eocene boundary, and is linked to the presence of a hot horizontal layer

520 beneath the lithosphere (Jones and White, 2003). Both processes could have caused

521 a significant portion of the Paleocene exhumation documented here. Although the

522 spatial distribution of Paleocene exhumation (centred along a north-south axis under

523 the Irish Sea) tends to favour the vertical convective sheet model, the temporal 
524 sensitivity of our low-temperature thermochronological data also allows for a more

525 widespread (but more subtle, at least in Ireland) phase of transient uplift as proposed

526 by Jones and White (2003). In any case, both mechanisms are linked to plume-

527 related (i.e. epeirogenic) regional-scale exhumation during the Early Cenozoic.

528 Following the Early Cenozoic exhumation phase, the thermal history models

529 indicate that some parts of onshore Ireland and Britain may have undergone a final

530 limited phase of cooling $\left(<\mathrm{ca} .30^{\circ} \mathrm{C}\right)$ during the Neogene period. A similar-magnitude

531 pulse of reheating often predates this cooling episode. However, the thermal history

532 models are not sensitive at temperatures below ca. $40^{\circ} \mathrm{C}$, as these temperatures are

533 cooler than the lower temperature limits of both the AHe and particularly the AFT

534 techniques. Nonetheless, Neogene uplift and exhumation of some parts of the British

535 Isles driven by plume-related processes is in agreement with the proposal that the 536 present-day topography of the British Isles is dynamically supported (e.g. Jones et

537 al., 2002; Davis et al., 2012; Rickers et al., 2013), and with the reported presence of 538 a "finger" of anomalously hot asthenosphere propagating from the Iceland plume 539 towards the Irish Sea region. The latter is visible in the upper asthenospheric mantle 540 on seismic tomographic images at depths of ca. 120 to $160 \mathrm{~km}$ (Arrowsmith et al., 541 2005; Rickers et al., 2013).

\section{Conclusions}

The use of two low-temperature thermochronometers (the AFT and AHe systems) combined with a vertical profile sampling approach and inverse and forward

547 modelling, allows us to define the cooling history of the British Isles, and especially 548 the Irish Sea region, with hitherto unparalleled resolution. From end Permian to 
549 Jurassic times, exhumation was likely linked to the uplift and erosion of the hinterland 550 during the complex and long-lived rifting history of the region, with each profile 551 recording a cooling phase synchronous with the major phase of rifting in the nearest 552 offshore basin. It is possible that during the Early Cretaceous period, transient 553 dynamic uplift was responsible for exhumation detected in two of our profiles, 554 although more work is needed to confirm this hypothesis. An Early Cenozoic pulse of 555 exhumation affected the onshore margins of the Irish Sea basin system, and is more 556 significant in the north (reaching ca. 2.5-3 km), decreasing in intensity towards the 557 south and west. Combined with the available geophysical and sedimentological 558 evidence, we demonstrate that the main cause of this regional-scale uplift and 559 exhumation is linked to the effects of the proto-Iceland plume. A body of magmatic 560 material emplaced into the base of the lower crust and which broadly corresponds in 561 seismic studies to the present-day limits of the BIPIP is likely to be the main causal 562 mechanism. It is also possible that transient dynamic support was responsible for a 563 component of the observed Early Cenozoic exhumation, while local reactivation 564 along discrete structures can account for local variations in the observed exhumation 565 pattern in the region. Subsequently, the late Cenozoic thermal history evolution of the 566 British Isles remains under-constrained, but a second phase of Neogene plume567 linked exhumation is possible.

568 The combination of AFT and AHe dating with vertical profile modelling has 569 proven key in resolving the hitherto disparate cooling histories documented in the 570 Irish Sea region during the Early Cenozoic. Persano et al. (2007) detected Early 571 Cenozoic underplating-driven uplift and denudation in western Scotland using a 572 similar approach; in both regions single-sample modelling of AFT data alone would 573 fail to detect the Early Cenozoic exhumation pulse (cf Fig. 7). Further AHe 
574 thermochronology from vertical profiles on onshore Britain would more precisely 575 constrain the region of influence of the proto-Iceland plume during the Early 576 Cenozoic.

577 Our data supports the hypothesis that the Early Cenozoic exhumation history 578 of the British Isles is linked to the presence of the Iceland Plume. The spatial 579 distribution of the BIPIP onshore follows the same axis as the distribution of 580 exhumation from the Outer Hebrides to Lundy Island. It is therefore likely that the 581 presence of abnormally hot vertical sheet of mantle centred below the Irish Sea 582 explains the relatively short wavelength of early Paleocene exhumation inferred for 583 the British Isles; seismic tomographic data suggest a similar situation may exist today 584 (Rickers et al., 2013).

585

\section{Acknowledgments}

NC and DC thank Science Foundation Ireland who part-funded this work under Grant Number 13/RC/2092 (iCRAG Research Centre, project HC4.2PD6a). iCRAG is funded under the SFI Research Centres Programme and is co-funded

590 under the European Regional Development Fund. DD is funded under The Earth and 591 Natural Sciences Doctoral Studies Program, which is funded under the Program for 592 Research in Third-Level Institutions and co-funded under the European Regional 593 Development Fund. We thank S. Jones and an anonymous reviewer for their 594 comments that significantly improved the manuscript. We would also like to thank S. 595 Lebedev and colleagues in the Dublin Institute of Advanced Studies for many useful 596 discussions.

\section{References}


Al Kindi, S., White, N.J., Sinha, M., England, R.W. \& Tiley, R., 2003. The crustal trace of a hot convective sheet, Geology, 31, 207-210.

Allen, P.A., Bennett, S.D., Cunningham, M.J.M., Carter, A., Gallagher, K., Lazzaretti, E., Galewsky, J., Densmore, A.L., Phillips, W.E.A., Naylor, D., Hach, C.S., 2002. The post-Variscan thermal and denudational history of Ireland. in: Doré, A.G., 604 Cartwright, M.S., Stoker, M.S., Turner, J.P., White, N. (Eds.). Exhumation of the North Atlantic margin: timing, mechanisms and implications for the petroleum exploration. Geological Society, London, Special Publications, 196, 371-399.

Arrowsmith, S.J., Kendall, M., White, N., VanDecar, J.C. \& Booth, D.C., 2005. 609348.

Blundell, D.J., 2002. Cenozoic inversion and uplift of Southern Britain, in Exhumation of the North Atlantic Margin: Timing, Mechanisms and Implications for Petroleum Exploration, in: Doré, A.G., Cartwright, M.S., Stoker, M.S., Turner, J.P., White, N. (Eds.). Exhumation of the North Atlantic margin: timing, mechanisms and implications for the petroleum exploration. Geological Society, London, Special Publications, 196, 85-101.

Braun, J., 2010. The many surface expressions of mantle dynamics. Nature Geosciences 3, 825-833.

Brodie, J., White, N., 1994. Sedimentary basin inversion caused by igneous underplating: Northwest European continental shelf. Geology 22, 147-150.

Burov, E., Cloetingh, S., 2009. Controls of mantle plumes and lithospheric folding on modes of intraplate continental tectonics: differences and similarities. Geophysical Journal International 178, 1691-1722.

Chew, D.M., Petrus, J.A., Kamber, B.S., 2014. U-Pb LA-ICPMS dating using accessory mineral standards with variable common Pb. Chemical Geology 363, 185199.

Cogné, N., Chew, D.M., Stuart, F.M., 2014. The thermal history of the western Irish onshore. Journal of the Geological Society, 171, 779-792.

Cope, J.C.W, 1994. A latest Cretaceous hotspot and the Southeasterly tilt of Britain. Journal of the Geological Society 151, 905-908. 
Cox, K., 1989, The role of mantle plumes in the development of continental drainage patterns. Nature 342, 873-877.

Davis, M.W., White, N.J., Priestley, K.F., Baptie B. J., Tilmann F.J., 2012. Crustal structure of the British Isles and its epeirogenic consequences. Geophysical Journal International 190, 705-725.

Donelick, R.A., O'Sullivan, P.B., Ketcham, R.A., 2005. Apatite Fission-Track Analysis. Reviews in Mineralogy and Geochemistry 58, 49-94.

Downing, R.A., Gray, D.A., 1986. Geothermal resources of the United Kingdom. Journal of the Geological Society $143,499-507$.

England, R.W., 1992. The genesis, ascent, and emplacement of the Northern Arran Granite, Scotland: Implications for granitic diapirism. Geological Society of America Bulletin 104, 606-614.

Flowers, R.M., Ketcham, R.A., Shuster, D.L., Farley, K.A., 2009. Apatite (U$\mathrm{Th}) / \mathrm{He}$ thermochronometry using a radiation damage accumulation and annealing model. Geochimica et Cosmochimica Acta 73, 2347-2365.

Foeken, J.P.T., Stuart, F.M., Dobson, K.J., Persano, C., Vilbert, D., 2006. A diode laser system for heating minerals for (U-Th)/He chronometry. Geochemistry, Geophysics, and Geosystems 7, Q04015.

Gallagher, K., 1995. Evolving temperature histories from apatite fission-track data. Earth and Planetary Science Letters 136, 421-435.

Gallagher, K., 2012. Transdimensional inverse thermal history modeling for quantitative thermochronology. Journal of Geophysical Research 117, B02408.

652 Gallagher, K., Stephenson, J., Brown, R., Holmes, C., Fitzgerald, P., 2005. Low 653 temperature thermochronology and modeling strategies for multiple samples 1 : 654 Vertical profiles. Earth and Planetary Science Letters 237, 193-208.

655 Ganerød, M., Smethurst, M.A., Torsvik, T.H., Prestvik, T., Rousse, S., McKenna, 656 C., van Hinsbergen, D.J.J., Hendriks, B.W.H., 2010. The North Atlantic Igneous 657 Province reconstructed and its relation to the Plume Generation Zone: the Antrim 658 Lava Group revisited. Geophysical Journal International 182, 183-202. 
Goodman, R., G.L., J., Kelly, J., Slowey, E., O’Neill, N., 2004. Geothermal Energy Resource Map of Ireland. Final Report.

661 Green, P. F. 2002. Early Tertiary paleo-thermal effects in Northern England: reconciling results from apatite fission track analysis with geological evidence. Tectonophysics 349, 131-144.

Green, P. F., Duddy, I. R. \& Bray, R. J. 1997. Variation in thermal history styles 665 around the Irish Sea and adjacent areas: implications for hydrocarbon occurrence and tectonic evolution. In: Meadows, N. S., Trueblood, S. P., Hardman, M. \& Cowan, G. (eds) Petroleum Geology of the Irish Sea and Adjacent Areas. Geological Society, London, Special Publications, 124, 73-93.

Green, P.F., Duddy, I.R., Hegarty, K.A., Bray, R.J., Sevastopulo, G., Clayton, G., Johnston, D., 2000. The post-Carboniferous evolution of Ireland: evidence from Thermal History Reconstruction. Proceedings of the Geologists' Association 111, 307-320.

Green, P.F., Crowhurst, P.V., Duddy, I.R., Japsen, P., Holford, S.P., 2006. Conflicting $(\mathrm{U}-\mathrm{Th}) / \mathrm{He}$ and fission track ages in apatite: Enhanced He retention, not anomalous annealing behaviour. Earth and Planetary Science Letters 250, 407-427.

Hillis, R.R., Holford, S.P., Green, P.F., Doré, A.G., Gatliff, R.W., Stoker, M.S., Thomson, K., Turner, J.P., Underhill, J.R., Williams, G.A., 2008. Cenozoic exhumation of the southern British Isles. Geology 36, 371-374.

Holford, S.P., Turner, J.P., Green, P.F., 2005. Reconstructing the Mesozoic Cenozoic exhumation history of the Irish Sea basin system using apatite fission track analysis and vitrinite reflectance data. Geological Society, London Petroleum 682 Geology Conference series 6, 1095-1107.

Jones, S., White, N., Clarke, B.J., Rowley, E., Gallagher, K., 2002. Present and 684 past influence of the Iceland Plume on sedimentation, in: Doré, A.G., Cartwright, M.S., Stoker, M.S., Turner, J.P., White, N. (Eds.). Exhumation of the North Atlantic 686 margin: timing, mechanisms and implications for the petroleum exploration. Geological Society, London, Special Publications, 196, 13-25. 
Jones, S.M., Lovell, B., Crosby, A.G., 2012. Comparison of modern and geological observations of dynamic support from mantle convection. Journal of the Geological Society $169,745-758$.

Jones, S.M., White, N., 2003. Shape and size of the starting Iceland plume swell, Earth and Planetary Science Letters 216, 271-282.

Kamerling, P., 1979. The geology and hydrocarbon habitat of the Bristol Channel Basin. Journal of Petroleum Geology 2, 75-93.

Ketcham, R.A., Carter, A., Donelick, R.A., Barbarand, J., Hurford, A.J., 2007. Improved modeling of fission-track annealing in apatite. American Mineralogist 92, 799-810.

Lewis, C. L. E., Green, P. F., Carter, A., Hurford, A. J. 1992. Elevated K/T palaeotemperatures throughout Northwest England: three kilometres of Tertiary erosion? Earth and Planetary Science Letters 112, 131 - 145.

Meesters, A.G.C.A., Dunai, T.J., 2002. Solving the production-diffusion equation for finite diffusion domains of various shapes: Part II. Application to cases with [alpha]-ejection and nonhomogeneous distribution of the source. Chemical Geology 186, 57-73.

Morton, A.C., 1982. Heavy minerals of Hampshire Basin Paleogene strata. Geological Magazine, 119, 463-476.

Naylor, D., Shannon, P.M., 2009. Geology of Offshore Ireland, in: Holland, C.H., 708 Sander, I.S. (Eds.). The geology of Ireland, 2nd edition. Dunedin Academic Press Itd, 709 Edinburgh, Scotland, pp. 405-460.

710 Persano, C., Barfod, D.N., Stuart, F.M., Bishop, P., 2007. Constraints on early 711 Cenozoic underplating-driven uplift and denudation of western Scotland from low 712 temperature thermochronometry. Earth and Planetary Science Letters 263, 404-419.

713 Rickers, F., Fichtner, A., Trampert, J., 2013. The Iceland-Jan Mayen plume 714 system and its impact on mantle dynamics in the North Atlantic region: Evidence 715 from full-waveform inversion. Earth and Planetary Science Letters 367, 39-51. 
Rowley, E., White, N., 1998. Inverse modelling of extension and denudation in 717 the East Irish Sea and surrounding areas. Earth and Planetary Science Letters, 161, 718 57-71.

719 Shuster, D.L., Farley, K.A., 2009. The influence of artificial radiation damage and 720 thermal annealing on helium diffusion kinetics in apatite. Geochimica et 721 Cosmochimica Acta 73, 183-196.

722 Simms, M.J., 2009. Permian and Mesozoic, in: Holland, C.H., Sander, I.S. (Eds.). 723 The Geology of Ireland, 2nd edition. Dunedin Academic Press, Edinburgh, Scotland, 724 pp. $311-332$.

725 Stuart, F.M., Ellam, R.M., Harrop, P.J., Fitton, J.G., Bell, B.R., 2000. Constraints 726 on mantle plumes from the helium isotopic composition of basalts from the 727 British Tertiary Igneous Province. Earth and Planetary Science Letters 177, 273-285.

728 Tiley, R., McKenzie D., White, N., 2003. The elastic thickness of the British Isles. 729 Journal of the Geological Society 160, $499-502$.

730 Tomlinson, J.P., Denton, P., Maguire, P.K.H., Booth, D.C., 2006. Analysis of the 731 crustal velocity structure of the British Isles using teleseismic receiver functions. 732 Geophysical Journal International 167, 223-237.

733 Welch, M.J. \& Turner, J.P. 2000. Triassic - Jurassic development of the St. 734 George's Channel basin, offshore Wales, UK. Marine and Petroleum Geology, 17(6), 735 723-750.

736 Williams, G.A., Turner, J. P., Holford, S. P., 2005. Inversion and exhumation of 737 the St George's Channel Basin, offshore Wales, UK. Journal of the Geological 738 Society $162,97-110$.

739 White, N., McKenzie, D., 1989. Magmatism at rift zones: the generation of 740 volcanic continental margins and flood basalts. Journal of Geophysical Research 94, $741 \quad 7685-77729$.

742 White, N., Lovell, B., 1997. Measuring the pulse of a plume with the sedimentary 743 record. Nature 387, 888-891. 
Ziegler, P.A., Cloetingh, S., and van Wees, J.-D., 1995. Dynamics of intra-plate

745 compressional deformation: The Alpine foreland and other examples:

746 Tectonophysics, 252, 7-59.

Figure Captions

750

751 Table 1: Fission track results.

752 'Lithology: Grt = Granitoid intrusion; Sst = Sandstone. Age: Camb = Cambrian; LDev

753 = Lower Devonian; Ord = Ordovician; Pal = Paleogene; $\mathrm{PreC}=$ Precambrian; UDev = 754 Upper Devonian.

$755 \quad{ }^{2}$ Number of counted spontaneous tracks.

$756{ }^{3}$ Sum of the individual grain ${ }^{238} \mathrm{U} /{ }^{43} \mathrm{Ca}$ ratios measured by ICPMS and weighted by 757 the counted area.

$758{ }^{4}$ Counted area.

$759{ }^{5}$ Constraint used for the inverse modelling: DA = Deposition age; $E A=$ Emplacement 760 age; $\mathrm{UPb}=$ apatite $\mathrm{U}-\mathrm{Pb}$ age (unpublished); $\mathrm{VM}=$ Variscan metamorphism 761

762 Table 2: (U-Th-Sm/He) results

764 Figure 1: Topographic map of the studied area showing the sample locations and the 765 localities discussed in the text. Inset: Location of the studied area on the Northwest 766 European margin.

768 Figure 2: Plot of $\mathrm{F}_{\mathrm{T}}$-corrected $(\mathrm{U}-\mathrm{Th}-\mathrm{Sm}) / \mathrm{He}$ vs AFT ages. The grey bars show the 769 timing of emplacement of the British-Irish Tertiary Igneous Province. 
771 Figure 3: Thermal history models from Wales. The black boxes are user-specified

772 temperature-time constraints. (a) Inverse model for the Snowdonia profile; (b) Inverse 773 and forward models for individual samples from Anglesey and Pembrokeshire; (c) 774 Inverse model for the Brecon Beacons profile.

776 Figure 4: Thermal history models of pseudo-vertical profiles from SE Ireland. The black boxes are user-specified temperature-time constraints. (a) Galtee Mountains; (b) Mount Leinster; (c) Slieve Bloom and (d) Lugnaquilla.

Figure 5: Thermal history models from the Isle of Man and Isle of Arran. The black boxes are user-specified temperature-time constraints. (a) Inverse and forward modelling of the Isle of Man profile; (b) Isle of Arran profile.

Figure 6: Thermal history models for Southern Uplands and northeast Ireland. The black boxes are user-specified temperature-time constraints. (a) Individual samples Sct-1 and Sct-2; (b) Inverse modelling of individual samples Ire-8, Ire-9 and Ire-10.

Figure 7: Comparison of thermal history models for the Snowdonia profile using thermochronological data from individual versus multiple samples. (a) Model with AFT and AHe data from three samples modelled using the vertical profile approach

791 (as presented in Fig. 3a); (b) Model with AFT data only from three samples modelled with the vertical profile approach; (c) Model with AFT and AHe data for sample Cu-3 
794 only is similar to the two other two individual samples $(\mathrm{Cu}-3,-4)$ and is presented in 795 supplementary material with the predictions.

796

797 Figure 8: Map of Britain and Ireland showing the spatial distribution of Early Cenozoic 798 exhumation phase inferred from our low-temperature thermochronological data and 799 its spatial relationship with the postulated region of magmatic underplating. The main 800 zones of Early Cenozoic deformation along with outcrops of post-Triassic 801 sedimentary rocks and the British-Irish Paleogene Igneous Province are also 802 illustrated. 


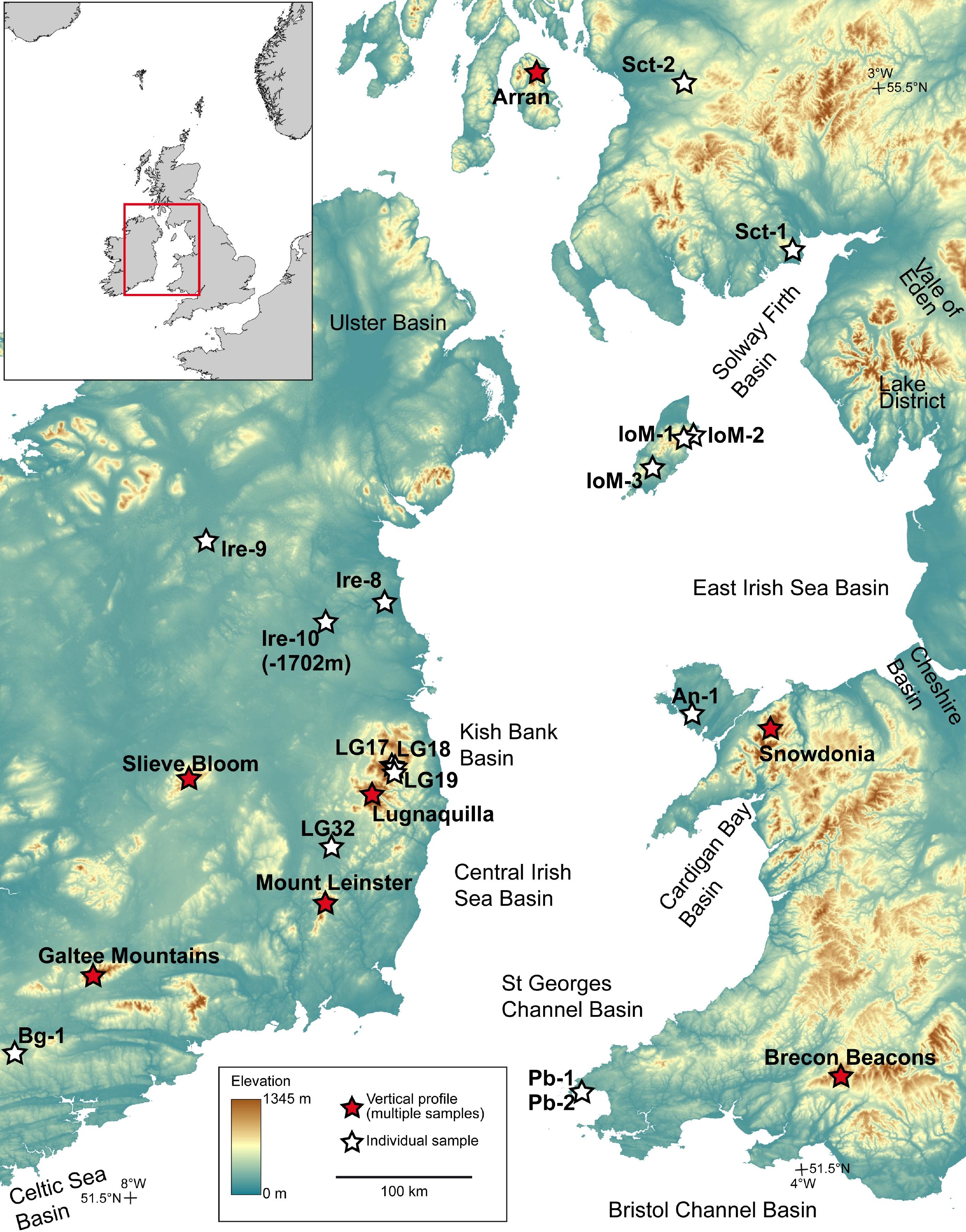


Figure 2

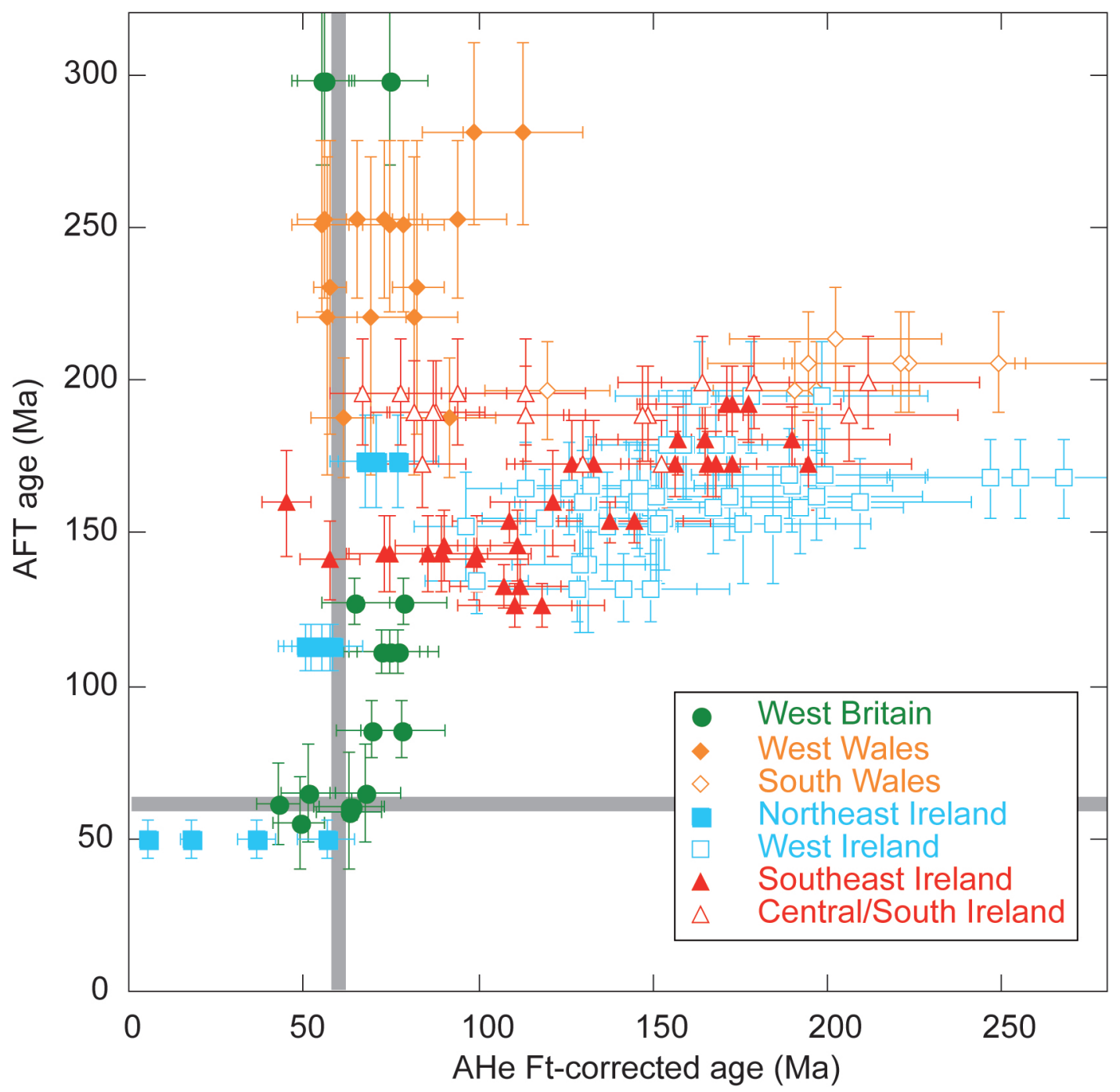


Figure 5

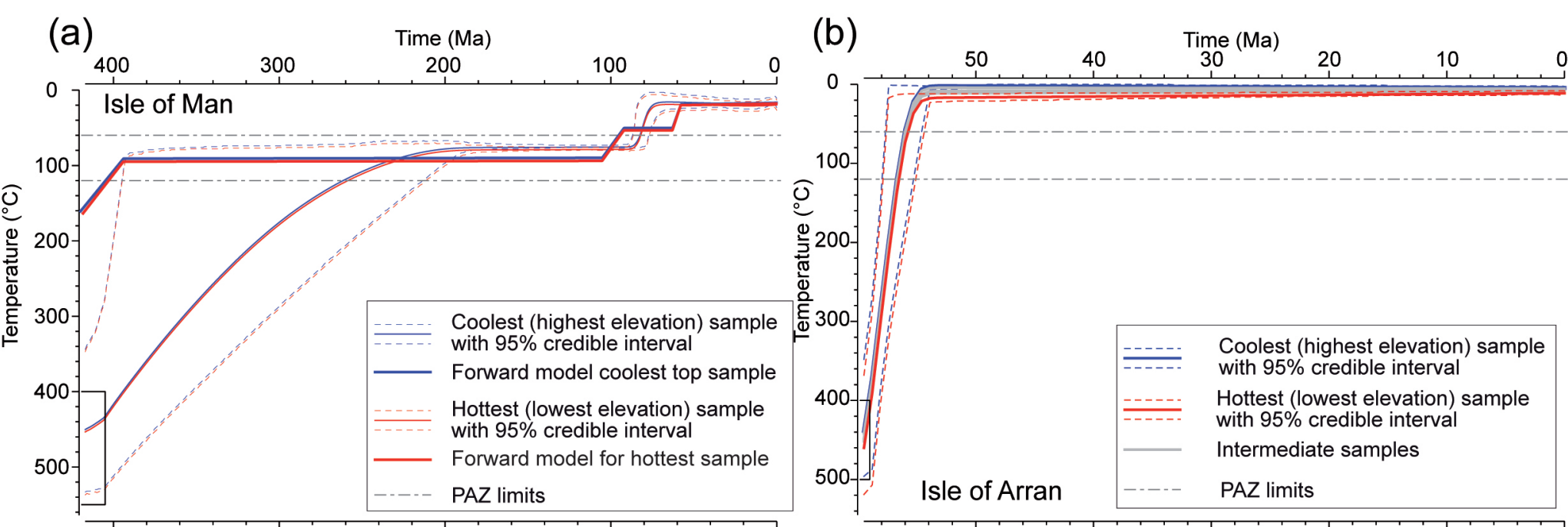




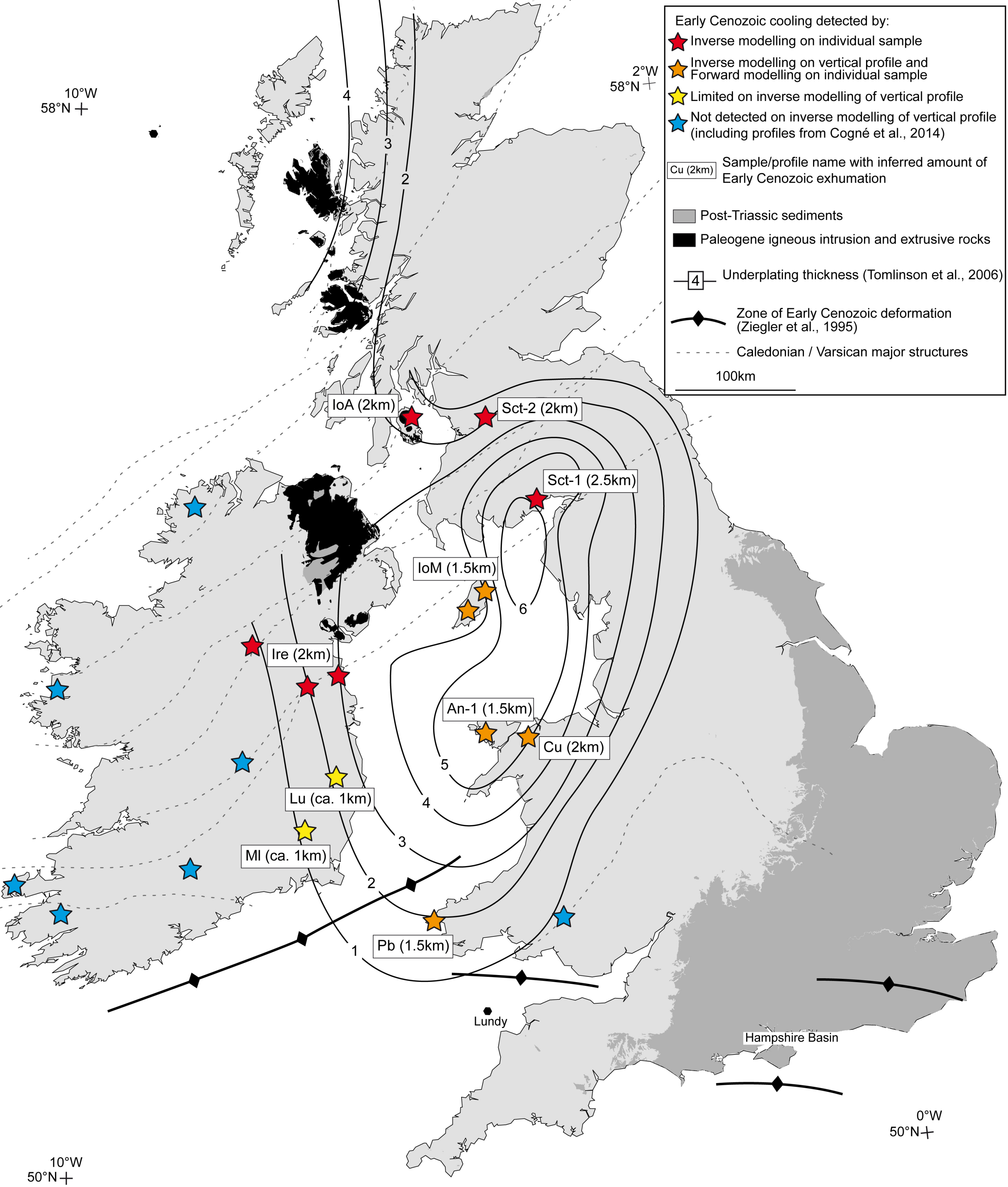


Sample Name

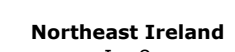
Ire 8
Ire 9
Ire 10

Ire 10
Central/South Ireland
$\mathrm{Bg}-1$

Bg-1
Galtee Mountains Profile

Ga-1
Ga-2
Ga-4

Slieve Bloom Profile $\mathrm{Sb}-1$
$\mathrm{Sb}-3$

Southeast Ireland

LG17
LG18

LG19
LG32

Lugnaquilla Profil

Lu-1
Lu-2

Lu-2
Lu-3
Lu-4

Lu-5

Mount Leinster Profile

$\mathrm{Ml}-1$
$\mathrm{Ml}-2$

$\mathrm{MI}-4$

North and West Wales

An-1

$\mathrm{Pb}-1$
Snowdonia Profile

Cu-3

$\mathrm{Cu}-4$
South Wales

Brecon Beacons Profile

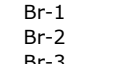

West Britain

West Britain
Isle of Man

IOM 1

IoM 3

Southern Upland

Sct 1
Sct 2

Isle of Arran Profile

IOA 1

IOA 2

IDA 4

IOA 4
IOA 5

IoA 6

$716 \quad 6.329$

N

$P\left(x^{2}\right)$

MTL ( $\mu \mathrm{m}) \quad \mathrm{SE}(\mu \mathrm{m})$ SD $(\mu \mathrm{m})$ \# tracks Dpar $(\mu \mathrm{m})$ SE $(\mu \mathrm{m})$ Tt constraint $^{5}$

$\begin{array}{lll}52.366 & 8.182 & 909\end{array}$

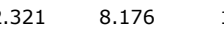

$\begin{array}{lll}53.092 & 7.557 & 437 \\ 53.138 & 7.528 & 142\end{array}$

$\begin{array}{lll}53.087 & 6.370 & 517\end{array}$

$\begin{array}{lll}53.087 & 6.362 & 553 \\ 53.066 & 6.337 & 389 \\ 52.804 & 6.717 & 122\end{array}$

$52.804 \quad 6.717$

$\begin{array}{ll}52.970 & 6.460 \\ 52.973 & 6.450\end{array}$

$\begin{array}{ll}52.979 & 6.443 \\ 52.982 & 6.439 \\ 52.994 & 6.426\end{array}$

$\begin{array}{ll}52.994 & 6.426 \\ 52.967 & 6.384\end{array}$

$52.618 \quad 6.780$

$\begin{array}{ll}52.618 & 6.787 \\ 52.611 & 6.799\end{array}$

$\begin{array}{ll}5.599 & 6.814\end{array}$

$\begin{array}{ll}53.232 & 4.488 \\ 51.866 & 5.282\end{array}$

$51.870 \quad 5.283$

$\begin{array}{ll}53.187 & 3.975 \\ 53.191 & 4.000\end{array}$

$\begin{array}{lll}53.191 & 4.000 & 70 \\ 53.209 & 3.994 & 327\end{array}$

$\begin{array}{lll}51.882 & 3.708 & 801 \\ 51.853 & 3.687 & 505\end{array}$

54.255
54.256

$\begin{array}{lll}54.255 & 4.378 & 239 \\ 54.256 & 4.365 & 162\end{array}$

$\begin{array}{lll}54.162 & 4.619 & 174\end{array}$

$\begin{array}{lll}54.940 & 3.630 & 559 \\ 55.588 & 4.224 & 240\end{array}$

$\begin{array}{lll}55.626 & 5.192 & 852 \\ 55.626 & 5.188 & 746\end{array}$

$\begin{array}{lll}55.626 & 5.188 & 746 \\ 55.623 & 5.177 & 535\end{array}$

$\begin{array}{ll}55.623 & 5.177 \\ 55.620 & 5.177\end{array}$

$\begin{array}{ll}55.620 & 5.177 \\ 55.617 & 5.178\end{array}$

$55.673 \quad 5.206 \quad 93$ \begin{tabular}{llll} 
Grt (Low Dev) & 1657 & $1.49 \mathrm{E}-04$ & $8.61 \mathrm{E}-04$ \\
Grt (Lw Dev) & 1018 & $5.74 \mathrm{E}-05$ & 8.01 \\
\hline & & 0.04
\end{tabular}

$\begin{array}{cccc}1018 & 5.74 \mathrm{E}-05 & 8.01 \mathrm{E}-04 \\ & 7.07 \mathrm{E}-05 & 4.68 \mathrm{E}-04\end{array}$

Sdt (Up Dev)

826

$4.65 \mathrm{E}-05 \quad 4.03 \mathrm{E}-04$

$3.47 \mathrm{E}-05 \quad 4.01 \mathrm{E}-04$

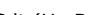

Grt (Low Dev)

Grt (Low Dev)

Grt (Low Dev)

Grt (Low Dev)

Grt (Low Dev)

Grt (Low Dev)

Grt (Low Dev)

Grt (Low Dev)

Grt (Low Dev)

Grt (Low Dev)
Grt (Low Dev)

Grt (Pre-Camb) Grt (Ord)
Sdt (Camb)

Grt (Ord)

Grt (Ord)

Grt (Ord)

Sdt (Up Dev)
Sdt (Up Dev)

Sdt (Up Dev)
Sdt (Up Dev)

dup Dev)

Grt (Dev)

Grt (Dev)

Grt (Low Dev)
Grt (Low Dev)

Grt (Pal)

Grt (Pal)

Grt (Pal)

Grt (Pal)

Grt (Pal)

3.12E-05 $\quad 1.16 \mathrm{E}-03$

$\begin{array}{ll}3.47 \mathrm{E}-05 & 3.29 \mathrm{E}-04 \\ 3.53 \mathrm{E}-05 & 2.83 \mathrm{E}-04\end{array}$

$\begin{array}{ll}3.02 \mathrm{E}-05 & 3.03 \mathrm{E}-04 \\ 6.00 \mathrm{E}-04 & \end{array}$

$\begin{array}{ll}6.10 \mathrm{E}-05 & 3.09 \mathrm{E}-04 \\ 6.71 \mathrm{E}-05 & 2.80 \mathrm{E}-04 \\ 3.65 \mathrm{E}-05 & 3.51 \mathrm{E}-04\end{array}$

3.65E-05 3.51E-04

5.94E-05 2.80E-04

$\begin{array}{ll}6.56 \mathrm{E}-05 & 3.01 \mathrm{E}-04 \\ 6.60 \mathrm{E}-05 & 3.16 \mathrm{E}-04\end{array}$

$\begin{array}{ll}6.60 \mathrm{E}-05 & 3.16 \mathrm{E}-04 \\ 9.12 \mathrm{E}-05 & 3.06 \mathrm{E}-04\end{array}$

8.94E-06 3.78E-04

$\begin{array}{ll}4.39 \mathrm{E}-06 & 4.43 \mathrm{E}-04 \\ 4.85 \mathrm{E}-06 & 3.27 \mathrm{E}-04\end{array}$

$\begin{array}{ll}1.49 \mathrm{E}-05 & 6.15 \mathrm{E}-04 \\ 1.43 \mathrm{E}-05 & 5.81 \mathrm{E}-04\end{array}$

$\begin{array}{ll}1.43 \mathrm{E}-05 & 5.81 \mathrm{E}-04 \\ & \end{array}$

$\begin{array}{ll}3.62 \mathrm{E}-05 & 7.49 \mathrm{E}-04 \\ 4.28 \mathrm{E}-05 & 7.79 \mathrm{E}-04\end{array}$

$1303 \quad 2.19 E-04 \quad 5.67 \mathrm{E}-04$

$\begin{array}{lll}622 & 2.02 \mathrm{E}-05 & 5.67 \mathrm{E}-04 \\ 3.96 \mathrm{E}-04\end{array}$

$\begin{array}{ccc}49 & 7.12 \mathrm{E}-06 & 3.82 \mathrm{E}-04 \\ 118 & 1.79-05 & 6.33 \mathrm{E}-04 \\ 5 & 1.37 E-05 & 1.76 E-04\end{array}$

$\begin{array}{ccc}59 & 1.37 \mathrm{E}-05 & 6.33 \mathrm{E}-04 \\ 1.76 \mathrm{E}-04\end{array}$

$\begin{array}{ccc}106 & 1.67 \mathrm{E}-05 & 3.34 \mathrm{E}-04 \\ 54 & 8.04 \mathrm{E}-06 & 2.15 \mathrm{E}-04 \\ 1 & 1.70 & \end{array}$

$\begin{array}{ccc}54 & 8.04 \mathrm{E}-06 & 2.15 \mathrm{E}-04 \\ 112 & 1.70 \mathrm{E}-05 & 3.40 \mathrm{E}-04\end{array}$ $\begin{array}{ll}5.25 \mathrm{E}-05 & 3.60 \mathrm{E}-04 \\ 4.69 \mathrm{E}-05 & 3.48 \mathrm{E}-04\end{array}$ $\begin{array}{llll}112.8 & 7.8 & 20 & 0.07 \\ 173.4 & 14.4 & 22 & 0.83\end{array}$

$\begin{array}{ccc}7.8 & 20 & 0.07 \\ 14.4 & 22 & 0.83 \\ 5.8 & 29 & 0.76\end{array}$

$\begin{array}{lll}15.4 & 30 & 0.11\end{array}$

$\begin{array}{lll}15.2 & 28 & 0.05 \\ 15.2 & 29 & 0.09\end{array}$

$1.68 \mathrm{E}-04 \quad 1.07 \mathrm{E}-03$

$\begin{array}{ll}2.34 \mathrm{E}-04 & 1.22 \mathrm{E}-03 \\ 2.01 \mathrm{E}-04 & 1.24 \mathrm{E}-03 \\ 3.12 \mathrm{E}-05 & 1\end{array}$

$\begin{array}{lll}736 & 3.56 \mathrm{E}-05 & 4.87 \mathrm{E}-04 \\ 779 & 3.62 \mathrm{E}-05 & 7.49 E-04\end{array}$

$\begin{array}{lll}800 & 6.25 \mathrm{E}-05 & 5.65 \mathrm{E}-04 \\ 765 & 6.85 \mathrm{E}-05 & 6.58 \mathrm{E}-04 \\ & 4.35 \mathrm{E}-05 & \end{array}$

$\begin{array}{llll}205.8 & 16.2 & 31 & 0.69\end{array}$

$\begin{array}{llll}16.6 & 29 & 0.87 \\ & 16.0 & 38 & 0.13\end{array}$

$\begin{array}{llll}127.6 & 11.0 & 20 & 0.01 \\ 111.2 & 10.0 & 21 & 0.02\end{array}$

$\begin{array}{llll}60.4 & 4.0 & 20 & 0.16 \\ 299.2 & 27.6 & 21 & 0.27\end{array}$

$\begin{array}{llll}70.6 & 18.8 & 18 & 0.99 \\ 61.1 & 13.4 & 19 & 0.11 \\ 43.3 & 15.6 & 7 & 0.93\end{array}$

$\begin{array}{llll}43.3 & 13.6 & 19 & 0.11 \\ 5 & 15 & 0.93\end{array}$

$\begin{array}{llll}55.3 & 15.0 & 15 & 0.99 \\ 59.1 & 18.8 & 10 & 0.97\end{array}$

64.9

0.97
0.99 $\begin{array}{lllllll}13.4 & 0.22 & 1.47 & 100 & 2.01 & 0.27 & \text { VM } \\ 13.7 & 0.17 & 1.09 & 101 & 1.78 & 0.19 & \text { VM } \\ 13.9 & 0.41 & 1.34 & 17 & 1.89 & 0.44 & \text { VM }\end{array}$

13.5

$\begin{array}{lllll}0.25 & 1.43 & 100 & 1.64 & 0.18\end{array}$

$\begin{array}{llllll}0.25 & 1.42 & 103 & 1.59 & 0.21\end{array}$

$\begin{array}{llllll}0.23 & 1.56 & 102 & 1.60 & 0.17 & \text { VM } \\ & 1.42 & 115 & 1.61 & 0.18 & \text { VM }\end{array}$

$0.22 \quad 1.31$

$\begin{array}{ll}1.31 & 100 \\ 1.42 & 102\end{array}$

$\begin{array}{lllllll}0.20 & 1.06 & 103 & 1.55 & 0.15 & \text { UPb } \\ 0.19 & 1.25 & 102 & 1.52 & 0.18 & \text { UPb }\end{array}$

$\begin{array}{llllll}0.19 & 1.16 & 102 & 1.55 & 0.18 & \text { UPb } \\ 0.18 & 1.22 & 100 & 1.52 & 0.21 & \text { UPb } \\ 0 & & & & & \end{array}$

$\begin{array}{llll}100 & 1.53 & 0.22 & \text { UPb }\end{array}$

$\begin{array}{lll}0.25 & 1.59 & 100\end{array}$

$\begin{array}{lll}0.26 & 1.8 & 100 \\ 0.25 & 1.64 & 100 \\ 0.25 & 1.63 & 100\end{array}$

$\begin{array}{lll}0.25 & 1.56 & 100 \\ 0.24 & 1.47 & 100\end{array}$

$\begin{array}{lll}0.27 & 1.46 & 100\end{array}$

$\begin{array}{lll}0.27 & 1.45 & 100 \\ 0.24 & 1.27 & 100 \\ 0.25 & 1.27 & 100\end{array}$

$0.18 \quad 1.82$

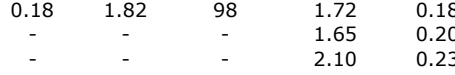

$\begin{array}{lllll}0.22 & 1.35 & 100 & 1.72 & 0.19 \\ 0.21 & 1.4 & 101 & 1.79 & 0.21 \\ 0.23 & 1.4 & 100 & 1.70 & 0.19\end{array}$

20.1 .39

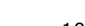

13.9
13.7

$\begin{array}{lll}0.22 & 1.39 & 100 \\ 0.20 & 1.27 & 102 \\ 0.21 & 1.43 & 100\end{array}$

$\begin{array}{ll}1.85 & 0.27\end{array}$

12.6

$\begin{array}{lllll}0.28 & 1.52 & 101 & 1.54 & 0.24\end{array}$

$\begin{array}{ll}1.54 & 0.24 \\ 1.67 & 0.22 \\ 1.48 & 0.21\end{array}$

13.7

$\begin{array}{lll}0.21 & 1.54 & 1.38\end{array}$

$\begin{array}{lllllll}0.17 & 1.19 & 103 & 1.63 & 0.24 & \text { UPb } \\ 0.23 & 1.43 & 104 & 2.03 & 0.38 & \text { UPb }\end{array}$

$\begin{array}{lllll}- & - & - & 1.35 & 0.26 \\ - & - & - & 1.37 & 0.21 \\ - & - & - & 1.36 & 0.15 \\ - & - & - & 1.44 & 0.19 \\ - & - & - & 1.38 & 0.25 \\ - & - & - & 1.41 & 0.23\end{array}$

EA 


\begin{tabular}{|c|c|c|c|c|c|c|c|c|c|c|c|c|c|}
\hline Sample & U(ppm) & $\operatorname{Th}(\mathrm{ppm})$ & $\mathrm{sm}(\mathrm{ppm})$ & Eu (ppm) & $\mathrm{Th} / \mathrm{U}$ & $\mathrm{He}(\mathrm{nmol} / \mathrm{g})$ & radius (um) & masse (ng) & Age (Ma) & $\pm 1 \sigma(\mathrm{Ma})$ & $F \mathrm{t}$ & Corrected age (Ma) & $\pm 1 \sigma(\mathrm{Ma})$ \\
\hline $\begin{array}{c}\text { Ire-8 } \\
-a \\
-b \\
-b \\
-d \\
-d \\
-e \\
\text { e- }\end{array}$ & $\begin{array}{l}40.00 \\
38.40 \\
49.60 \\
57.10 \\
48.80\end{array}$ & $\begin{array}{l}149.30 \\
177.68 \\
162.280 \\
226.32 \\
153.35\end{array}$ & $\begin{array}{l}37.30 \\
40.32 \\
31.50\end{array}$ & $\begin{array}{l}75.27 \\
79.92 \\
88.06 \\
110.28 \\
85.00\end{array}$ & $\begin{array}{l}3.73 \\
4.60 \\
3.28 \\
3.96 \\
3.14\end{array}$ & 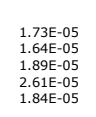 & $\begin{array}{l}58.44 \\
56.87 \\
56.43 \\
52.40 \\
49.29\end{array}$ & $\begin{array}{l}6.40 \\
5.50 \\
5.14 \\
3.69 \\
3.24\end{array}$ & $\begin{array}{l}42.4 \\
37.9 \\
39.5 \\
43.6 \\
40.0\end{array}$ & $\begin{array}{l}3.4 \\
3.0 \\
3.2 \\
3.5 \\
3.2\end{array}$ & $\begin{array}{l}0.73 \\
0.75 \\
0.75 \\
0.75 \\
0.73\end{array}$ & $\begin{array}{l}58.0 \\
50.5 \\
52.5 \\
58.4 \\
55.1\end{array}$ & $\begin{array}{l}4.6 \\
4.0 \\
4.2 \\
4.7 \\
4.4\end{array}$ \\
\hline $\begin{array}{c}c-9 \\
-a \\
-d \\
-e \\
-e\end{array}$ & $\begin{array}{l}12.80 \\
19.30 \\
12.70\end{array}$ & $\begin{array}{l}58.30 \\
77.10 \\
59.60\end{array}$ & $\begin{array}{l}21.60 \\
20.20\end{array}$ & $\begin{array}{l}26.61 \\
37.42 \\
26.81\end{array}$ & $\begin{array}{l}4.55 \\
3.99 \\
4.69\end{array}$ & $\begin{array}{l}8.14 E-06 \\
1.188-05 \\
7.11 E-06\end{array}$ & $\begin{array}{l}66.79 \\
64.15 \\
49.67\end{array}$ & $\begin{array}{l}7.77 \\
7.80 \\
3.45\end{array}$ & $\begin{array}{l}56.4 \\
58.0 \\
48.9\end{array}$ & $\begin{array}{l}4.5 \\
4.6 \\
3.9\end{array}$ & $\begin{array}{l}0.80 \\
0.75 \\
0.72\end{array}$ & $\begin{array}{l}70.9 \\
777.1 \\
67.8\end{array}$ & $\begin{array}{l}5.7 \\
6.2 \\
5.4\end{array}$ \\
\hline 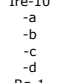 & $\begin{array}{l}30.74 \\
3.83 \\
42.28 \\
24.92\end{array}$ & 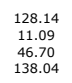 & $\begin{array}{l}23.95 \\
4.24 \\
34.70\end{array}$ & $\begin{array}{l}60.97 \\
66.43 \\
15.28 \\
57.53\end{array}$ & $\begin{array}{l}4.17 \\
2.90 \\
10.91 \\
5.54\end{array}$ & 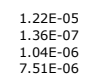 & $\begin{array}{l}43.25 \\
46.71 \\
45.22 \\
39.97 \\
39.97\end{array}$ & $\begin{array}{l}2.84 \\
2.68 \\
2.73 \\
1.95\end{array}$ & $\begin{array}{l}36.5 \\
3.9 \\
11.5 \\
23.9\end{array}$ & $\begin{array}{l}2.9 \\
0.3 \\
1.0 \\
1.9\end{array}$ & $\begin{array}{l}0.65 \\
0.75 \\
0.71 \\
0.65\end{array}$ & $\begin{array}{l}56.5 \\
5.2 \\
17.7 \\
36.7\end{array}$ & $\begin{array}{l}4.5 \\
0.4 \\
1.4 \\
2.9\end{array}$ \\
\hline $\begin{array}{c}b 9-1 \\
=a \\
-b \\
-d \\
-d \\
-e\end{array}$ & $\begin{array}{l}44.4 \\
18.2 \\
9.6 \\
14.7\end{array}$ & $\begin{array}{l}32.9 \\
22.1 \\
11.7 \\
68.2\end{array}$ & $\begin{array}{l}12.1 \\
6.77 \\
38.8 \\
28.5\end{array}$ & $\begin{array}{l}52.2 \\
22.4 \\
13.5 \\
30.9\end{array}$ & $\begin{array}{l}0.74 \\
1.222 \\
1.23 \\
4.63\end{array}$ & $\begin{array}{l}4.999-05 \\
1.544-05 \\
5.51-0 .-06 \\
1.85 E-05\end{array}$ & $\begin{array}{l}79.0 \\
69.7 \\
44.3 \\
47.0\end{array}$ & $\begin{array}{l}9.67 \\
7.94 \\
2.28 \\
2.87\end{array}$ & $\begin{array}{l}174.9 \\
118.3 \\
15.4 \\
106.4\end{array}$ & $\begin{array}{l}14.0 \\
9.5 \\
6.0 \\
8.5\end{array}$ & $\begin{array}{l}0.847 \\
0.796 \\
0.662 \\
0.725\end{array}$ & $\begin{array}{l}206.5 \\
148.6 \\
113.8 \\
146.7\end{array}$ & $\begin{array}{l}16.5 \\
11.9 \\
9.1 \\
11.7\end{array}$ \\
\hline 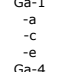 & $\begin{array}{l}25.3 \\
20.2 \\
30.6\end{array}$ & $\begin{array}{l}86.5 \\
4.6 \\
53.7\end{array}$ & $\begin{array}{l}189.5 \\
25.0\end{array}$ & $\begin{array}{l}46.6 \\
21.4 \\
43.2\end{array}$ & $\begin{array}{l}3.42 \\
0.23 \\
1.76\end{array}$ & $\begin{array}{l}1.87 E-05 \\
1.395-05 \\
1.995-05 \\
4.95-05\end{array}$ & $\begin{array}{l}48.0 \\
43.2 \\
42.5\end{array}$ & $\begin{array}{l}1.99 \\
1.90 \\
1.54\end{array}$ & $\begin{array}{l}148.9 \\
112.0 \\
120.7\end{array}$ & $\begin{array}{l}11.9 \\
9.0 \\
9.7\end{array}$ & $\begin{array}{l}0.704 \\
0.681 \\
0.674\end{array}$ & $\begin{array}{l}211.5 \\
164.5 \\
179.1\end{array}$ & $\begin{array}{l}16.9 \\
13.2 \\
14.3\end{array}$ \\
\hline $\begin{array}{c}-a \\
-e \\
-c \\
-c \\
c-1\end{array}$ & $\begin{array}{l}\begin{array}{l}16.2 \\
3.1 \\
15.2\end{array} \\
1.2\end{array}$ & $\begin{array}{c}7.7 \\
45.1 \\
0.0\end{array}$ & $\begin{array}{c}\vdots \\
19.9\end{array}$ & 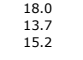 & $\begin{array}{l}0.47 \\
14.66 \\
0.00\end{array}$ & $\begin{array}{l}2.45 E-5 \\
4.072-06 \\
3.40-06\end{array}$ & $\begin{array}{l}75.1 \\
38.5 \\
45.0\end{array}$ & $\begin{array}{l}9.82 \\
1.30 \\
1.78\end{array}$ & $\begin{array}{l}105.5 \\
54.4 \\
104.3\end{array}$ & $\begin{array}{l}8.4 \\
4.4 \\
8.3\end{array}$ & $\begin{array}{l}0.811 \\
0.646 \\
0.6855\end{array}$ & $\begin{array}{l}130.1 \\
84.2 \\
152.3\end{array}$ & $\begin{array}{l}10.4 \\
6.7 \\
12.2\end{array}$ \\
\hline $\begin{array}{c}-b \\
-b \\
-c \\
-e \\
s b-3\end{array}$ & $\begin{array}{l}5.3 \\
4.1 \\
8.2\end{array}$ & $\begin{array}{l}2.5 \\
14.1 \\
2.0\end{array}$ & $\vdots$ & $\begin{array}{l}5.9 \\
77.4 \\
8.7\end{array}$ & $\begin{array}{l}0.47 \\
3.43 \\
0.25\end{array}$ & $\begin{array}{l}2.292-0.06 \\
2.811-06 \\
3.21 E-06\end{array}$ & $\begin{array}{l}75.7 \\
56.2 \\
42.3\end{array}$ & $\begin{array}{l}9.66 \\
4.04 \\
1.76\end{array}$ & $\begin{array}{l}71.7 \\
64.6 \\
58.9\end{array}$ & $\begin{array}{l}5.7 \\
5.2 \\
4.7\end{array}$ & $\begin{array}{l}0.812 \\
0.792 \\
0.674\end{array}$ & $\begin{array}{l}88.3 \\
81.5 \\
87.4\end{array}$ & $\begin{array}{l}7.1 \\
6.5 \\
7.0\end{array}$ \\
\hline $\begin{array}{c}S_{0-3}^{-3} \\
-a \\
-b \\
-c \\
-d \\
-d\end{array}$ & $\begin{array}{l}2.6 \\
7.0 \\
9.9 \\
22.1\end{array}$ & $\begin{array}{l}35.2 \\
61.7 \\
12.6 \\
38.0\end{array}$ & $\vdots$ & $\begin{array}{l}10.9 \\
21.5 \\
11.9 \\
31.1\end{array}$ & $\begin{array}{l}13.39 \\
8.84 \\
1.27 \\
1.72\end{array}$ & $\begin{array}{l}1.55 E-05 \\
2.455-05 \\
3.559-06 \\
1.47 E-05\end{array}$ & $\begin{array}{l}68.5 \\
52.2 \\
43.0 \\
55.6\end{array}$ & $\begin{array}{l}7.42 \\
4.14 \\
1.39 \\
5.09\end{array}$ & $\begin{array}{l}53.3 \\
68.9 \\
52.3 \\
85.4\end{array}$ & $\begin{array}{l}4.3 \\
5.5 \\
4.2 \\
6.8\end{array}$ & $\begin{array}{l}0.792 \\
0.771 \\
0.67 \\
0.75\end{array}$ & $\begin{array}{l}67.3 \\
94.3 \\
78.1 \\
113.9\end{array}$ & $\begin{array}{l}5.4 \\
7.5 \\
6.2 \\
9.1\end{array}$ \\
\hline 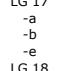 & $\begin{array}{l}42.20 \\
30.00 \\
34.00\end{array}$ & $\begin{array}{r}6.70 \\
5.50 \\
34.80\end{array}$ & $\begin{array}{c}- \\
19.30\end{array}$ & $\begin{array}{l}43.77 \\
31.29 \\
42.27\end{array}$ & $\begin{array}{l}0.16 \\
0.18 \\
1.02\end{array}$ & $\begin{array}{l}2.62 E-05 \\
1.75-5 \\
1.76-05 \\
1.76-05\end{array}$ & $\begin{array}{l}49.42 \\
61.24 \\
45.68\end{array}$ & $\begin{array}{l}3.54 \\
6.20 \\
2.59\end{array}$ & $\begin{array}{l}110.1 \\
102.5 \\
77.0\end{array}$ & $\begin{array}{l}8.8 \\
8.2 \\
6.2\end{array}$ & $\begin{array}{l}0.76 \\
0.74 \\
0.71\end{array}$ & $\begin{array}{l}145.0 \\
137.8 \\
109.0\end{array}$ & $\begin{array}{c}11.6 \\
11.0 \\
8.7\end{array}$ \\
\hline $\begin{array}{c}-a \\
-a \\
-b \\
1619\end{array}$ & $\begin{array}{l}23.95 \\
22.60\end{array}$ & $\begin{array}{l}7.30 \\
2.29\end{array}$ & $\begin{array}{l}22.40 \\
27.67\end{array}$ & $\begin{array}{l}25.78 \\
23.28\end{array}$ & $\begin{array}{l}0.30 \\
0.10\end{array}$ & $\begin{array}{l}1.196-05 \\
9.03 E-06\end{array}$ & $\begin{array}{l}53.44 \\
48.27\end{array}$ & $\begin{array}{l}3.96 \\
2.95\end{array}$ & $\begin{array}{l}85.4 \\
71.8\end{array}$ & $\begin{array}{l}6.8 \\
5.7\end{array}$ & $\begin{array}{l}0.77 \\
0.67\end{array}$ & $\begin{array}{l}\begin{array}{l}111.6 \\
107.6\end{array} \\
{ }_{10}\end{array}$ & $\begin{array}{l}8.9 \\
8.6\end{array}$ \\
\hline $\begin{array}{c}-a \\
-a \\
-d\end{array}$ & $\begin{array}{l}24.60 \\
39.50\end{array}$ & $\begin{array}{l}1.10 \\
0.80\end{array}$ & $\begin{array}{l}20.60 \\
39.20\end{array}$ & $\begin{array}{l}24.96 \\
39.88\end{array}$ & $\begin{array}{l}0.04 \\
0.02\end{array}$ & $\begin{array}{l}1.26 E=05 \\
1.98 E-05\end{array}$ & $\begin{array}{l}63.06 \\
55.32\end{array}$ & $\begin{array}{l}6.44 \\
4.36\end{array}$ & $\begin{array}{l}93.1 \\
91.4\end{array}$ & $\begin{array}{l}7.4 \\
7.3\end{array}$ & $\begin{array}{l}0.84 \\
0.77\end{array}$ & $\begin{array}{l}110.5 \\
118.1\end{array}$ & $\begin{array}{l}8.8 \\
9.4\end{array}$ \\
\hline $\begin{array}{c}-a \\
-a \\
-b \\
c \\
c\end{array}$ & $\begin{array}{l}4.50 \\
6.80 \\
20.80\end{array}$ & $\begin{array}{l}29.96 \\
50.21 \\
183.21\end{array}$ & $\begin{array}{l}14.86 \\
22.60 \\
22.65\end{array}$ & $\begin{array}{l}11.62 \\
18.71 \\
63.97\end{array}$ & $\begin{array}{l}6.66 \\
7.38 \\
8.81\end{array}$ & $\begin{array}{l}4.73 E-06 \\
7.615-06 \\
3.23 E-05\end{array}$ & $\begin{array}{l}66.61 \\
72.09 \\
86.36\end{array}$ & $\begin{array}{l}7.60 \\
9.87 \\
16.54\end{array}$ & $\begin{array}{l}75.3 \\
75.1 \\
93.2\end{array}$ & $\begin{array}{l}6.0 \\
6.0 \\
7.5\end{array}$ & $\begin{array}{l}0.84 \\
0.83 \\
0.84\end{array}$ & $\begin{array}{l}89.9 \\
90.1 \\
111.2\end{array}$ & $\begin{array}{l}7.2 \\
7.2 \\
8.9\end{array}$ \\
\hline $\begin{array}{c}-1 \\
-a \\
-b \\
-c \\
c u-3 \\
L u-3\end{array}$ & $\begin{array}{l}96.1 \\
24.2 \\
25.6\end{array}$ & $\begin{array}{l}1.5 \\
4.7 \\
5.8\end{array}$ & $\begin{array}{l}21.6 \\
30.0 \\
31.1\end{array}$ & $\begin{array}{l}96.6 \\
25.4 \\
27.2\end{array}$ & $\begin{array}{l}0.02 \\
0.20 \\
0.33\end{array}$ & $\begin{array}{l}8.69 E-05 \\
1.425-05 \\
1.48 E=-05\end{array}$ & $\begin{array}{l}93.1 \\
55.5 \\
60.9\end{array}$ & $\begin{array}{l}18.41 \\
3.93 \\
5.59\end{array}$ & $\begin{array}{l}164.6 \\
103.1 \\
98.5\end{array}$ & $\begin{array}{l}13.2 \\
8.2 \\
7.9\end{array}$ & $\begin{array}{l}0.845 \\
0.777 \\
0.776\end{array}$ & $\begin{array}{l}194.8 \\
132.7 \\
126.9\end{array}$ & $\begin{array}{l}15.6 \\
10.6 \\
10.2\end{array}$ \\
\hline $\begin{array}{c}-b \\
-d \\
-d \\
L-4\end{array}$ & $\begin{array}{l}21.3 \\
1.9\end{array}$ & $\begin{array}{l}{ }_{27.1}^{17} \\
2.0\end{array}$ & $\begin{array}{l}10.7 \\
5.1\end{array}$ & $\begin{array}{l}\begin{array}{l}25.4 \\
2.3\end{array} \\
\end{array}$ & $\begin{array}{l}0.80 \\
1.06\end{array}$ & $\begin{array}{l}1.373-05 \\
4.25 E-07\end{array}$ & $\begin{array}{l}66.9 \\
50.7\end{array}$ & $\begin{array}{l}7.16 \\
3.33\end{array}$ & $\begin{array}{l}98.6 \\
33.7\end{array}$ & $\begin{array}{l}7.9 \\
2.7\end{array}$ & $\begin{array}{l}0.812 \\
0.748\end{array}$ & $\begin{array}{l}121.4 \\
45.1\end{array}$ & $\begin{array}{l}9.7 \\
3.6\end{array}$ \\
\hline $\begin{array}{c}-b \\
-c \\
-d \\
-d u \\
\text { Lu-6 }\end{array}$ & $\begin{array}{l}4.4 \\
1.0 \\
5.3\end{array}$ & $\begin{array}{l}3.5 \\
0.3 \\
24.4 \\
24.4\end{array}$ & $\begin{array}{l}18.5 \\
\text { 3.2 } \\
53.6\end{array}$ & $\begin{array}{c}5.4 \\
1.1 \\
11.3\end{array}$ & $\begin{array}{l}0.80 \\
0.28 \\
4.62\end{array}$ & $\begin{array}{l}1.27 E-06 \\
2.744-07 \\
4.22 E-06\end{array}$ & $\begin{array}{l}54.6 \\
73.2 \\
48.0\end{array}$ & $\begin{array}{l}4.06 \\
9.72 \\
1.88\end{array}$ & $\begin{array}{l}44.2 \\
47.4 \\
69.8\end{array}$ & $\begin{array}{l}3.5 \\
3.8 \\
5.6\end{array}$ & $\begin{array}{l}0.766 \\
0.886 \\
0.704\end{array}$ & $\begin{array}{l}57.6 \\
57.4 \\
99.2\end{array}$ & $\begin{array}{l}4.6 \\
4.6 \\
7.9\end{array}$ \\
\hline $\begin{array}{c}c \\
-a \\
-b \\
-c \\
-d \\
-d \\
-e\end{array}$ & $\begin{array}{l}27.7 \\
38.3 \\
36.5 \\
39.6 \\
23.2\end{array}$ & $\begin{array}{l}2.8 \\
0.4 \\
3.1 \\
0.4 \\
0.3\end{array}$ & $\begin{array}{l}23.9 \\
20.2 \\
11.1 \\
25.3 \\
21.4\end{array}$ & $\begin{array}{l}28.5 \\
33.5 \\
37.3 \\
33.9 \\
23.4\end{array}$ & $\begin{array}{l}0.10 \\
0.01 \\
0.08 \\
0.01 \\
0.01\end{array}$ & $\begin{array}{l}8.97 E-06 \\
1.40-05 \\
1.440-05 \\
1.54-05 \\
1.311 E-05 \\
1.31-05\end{array}$ & $\begin{array}{l}51.3 \\
53.1 \\
63.2 \\
50.3 \\
42.0\end{array}$ & $\begin{array}{l}3.15 \\
3.47 \\
6.29 \\
2.19 \\
1.71\end{array}$ & $\begin{array}{l}58.3 \\
66.0 \\
71.3 \\
71.5 \\
51.9\end{array}$ & $\begin{array}{l}4.7 \\
5.3 \\
5.7 \\
5.7 \\
4.2\end{array}$ & $\begin{array}{l}0.783 \\
0.778 \\
0.777 \\
0.776 \\
0.71\end{array}$ & $\begin{array}{l}74.5 \\
86.0 \\
89.4 \\
99.9 \\
73.1\end{array}$ & $\begin{array}{l}6.0 \\
6.9 \\
7.2 \\
8.0 \\
5.8\end{array}$ \\
\hline $\begin{array}{c}c=1 \\
-\mathrm{a} \\
-\mathrm{b} \\
-\mathrm{c} \\
\mathrm{M} / 3\end{array}$ & $\begin{array}{l}52.1 \\
46.4 \\
52.9\end{array}$ & $\begin{array}{l}15.9 \\
66.9 \\
45.5\end{array}$ & $\begin{array}{l}26.6 \\
22.8 \\
17.6\end{array}$ & $\begin{array}{l}55.9 \\
48.2 \\
63.7\end{array}$ & $\begin{array}{l}0.30 \\
0.15 \\
0.86\end{array}$ & 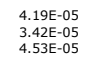 & $\begin{array}{l}57.0 \\
52.8 \\
50.6\end{array}$ & $\begin{array}{l}4.63 \\
3.79 \\
3.12\end{array}$ & $\begin{array}{l}137.6 \\
130.5 \\
128.9\end{array}$ & $\begin{array}{l}11.0 \\
10.4 \\
10.3\end{array}$ & $\begin{array}{l}0.775 \\
0.775 \\
0.752\end{array}$ & $\begin{array}{l}177.5 \\
172.4 \\
171.5\end{array}$ & $\begin{array}{l}14.2 \\
13.8 \\
13.7\end{array}$ \\
\hline $\begin{array}{c}-\mathrm{a} \\
-\mathrm{b} \\
-\mathrm{e} \\
\mathrm{m} / 4\end{array}$ & $\begin{array}{l}49.3 \\
66.7 \\
45.6\end{array}$ & $\begin{array}{l}6.9 \\
5.9 \\
8.6\end{array}$ & $\begin{array}{l}33.0 \\
25.3 \\
17.4\end{array}$ & $\begin{array}{l}51.1 \\
68.2 \\
47.7\end{array}$ & $\begin{array}{l}0.14 \\
0.09 \\
0.19\end{array}$ & $\begin{array}{l}3.565-05 \\
5.575-05 \\
2.68 E-05\end{array}$ & $\begin{array}{l}64.4 \\
68.3 \\
37.3\end{array}$ & $\begin{array}{l}6.48 \\
6.35 \\
1.07\end{array}$ & $\begin{array}{l}126.4 \\
149.7 \\
103.4\end{array}$ & $\begin{array}{l}10.1 \\
12.0 \\
8.3\end{array}$ & $\begin{array}{l}0.803 \\
0.79 \\
0.626\end{array}$ & $\begin{array}{l}157.5 \\
189.4 \\
165.2\end{array}$ & 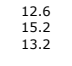 \\
\hline $\begin{array}{c}-a \\
-b \\
-c \\
-c \\
-d \\
A n-1\end{array}$ & $\begin{array}{l}72.8 \\
58.6 \\
91.8 \\
91.4\end{array}$ & $\begin{array}{l}3.0 \\
3.7 \\
4.8 \\
1.0\end{array}$ & $\begin{array}{l}25.2 \\
25.4 \\
3.1 .3 \\
16.4\end{array}$ & $\begin{array}{l}73.7 \\
59.6 \\
93.1 \\
91.7\end{array}$ & $\begin{array}{l}0.04 \\
0.06 \\
0.05 \\
0.01\end{array}$ & $\begin{array}{l}5.44-0.5 \\
4.111-05 \\
7.26-05 \\
5.977-05\end{array}$ & $\begin{array}{c}60.2 \\
66.2 \\
58.5 \\
39.6\end{array}$ & $\begin{array}{l}4.86 \\
6.75 \\
4.82 \\
1.38\end{array}$ & $\begin{array}{l}134.4 \\
126.9 \\
141.8 \\
117.0\end{array}$ & $\begin{array}{l}10.8 \\
10.2 \\
111.3 \\
9.4\end{array}$ & $\begin{array}{l}0.799 \\
0.811 \\
0.882 \\
0.705\end{array}$ & $\begin{array}{l}168.2 \\
156.4 \\
172.5 \\
166.0\end{array}$ & $\begin{array}{l}13.5 \\
112.5 \\
113.8 \\
13.3\end{array}$ \\
\hline $\begin{array}{l}-a \\
\text {-e } \\
\text { ee }\end{array}$ & $\begin{array}{l}5.8 \\
3.9\end{array}$ & $\begin{array}{l}16.7 \\
9.5\end{array}$ & $\begin{array}{l}1.0 \\
2.7\end{array}$ & $\begin{array}{l}9.7 \\
6.2\end{array}$ & $\begin{array}{r}2.88 \\
2.44\end{array}$ & $\begin{array}{l}1.844 E-06 \\
1.09 E-06\end{array}$ & $\begin{array}{l}38.9 \\
42.9\end{array}$ & $\begin{array}{l}1.59 \\
2.04\end{array}$ & $\begin{array}{l}59.7 \\
45.1\end{array}$ & $\begin{array}{l}4.8 \\
3.6\end{array}$ & $\begin{array}{l}0.65 \\
0.74\end{array}$ & $\begin{array}{l}91.5 \\
61.1\end{array}$ & $\begin{array}{l}7.3 \\
4.9\end{array}$ \\
\hline $\begin{array}{c}c-1 \\
=-1 \\
-b \\
-e \\
p b-2\end{array}$ & $\begin{array}{l}2.5 \\
3.4 \\
2.4\end{array}$ & $\begin{array}{l}13.4 \\
20.3 \\
25.9\end{array}$ & $\begin{array}{c}0.8 \\
15.3 \\
0.0\end{array}$ & $\begin{array}{l}5.7 \\
8.2 \\
8.5\end{array}$ & $\begin{array}{l}5.36 \\
5.57 \\
10.79\end{array}$ & $\begin{array}{l}9.828 E-07 \\
1.395-06 \\
1.25 E-06\end{array}$ & $\begin{array}{l}35.4 \\
42.9 \\
35.9\end{array}$ & $\begin{array}{l}1.20 \\
2.11 \\
1.22\end{array}$ & $\begin{array}{l}44.7 \\
55.0 \\
37.5\end{array}$ & $\begin{array}{l}3.6 \\
4.4 \\
3.0\end{array}$ & $\begin{array}{l}0.65 \\
0.67 \\
0.66\end{array}$ & $\begin{array}{l}68.9 \\
81.8 \\
56.9\end{array}$ & $\begin{array}{l}5.5 \\
6.5 \\
4.5\end{array}$ \\
\hline $\begin{array}{c}-b \\
-b \\
-d\end{array}$ & $\begin{array}{l}2.1 \\
2.2\end{array}$ & $\begin{array}{l}14.8 \\
7.8\end{array}$ & $\begin{array}{l}41.8 \\
27.6\end{array}$ & $\begin{array}{l}5.8 \\
4.2\end{array}$ & $\begin{array}{l}7.05 \\
3.55\end{array}$ & $\begin{array}{l}7.899-07 \\
9.69 E-07\end{array}$ & $\begin{array}{l}58.4 \\
41.7\end{array}$ & $\begin{array}{l}5.44 \\
2.04\end{array}$ & $\begin{array}{l}43.5 \\
58.2\end{array}$ & $\begin{array}{l}3.5 \\
4.7\end{array}$ & $\begin{array}{l}0.76 \\
0.70\end{array}$ & $\begin{array}{l}57.5 \\
82.8\end{array}$ & $\begin{array}{l}4.6 \\
6.6\end{array}$ \\
\hline $\begin{array}{c}c u-3 \\
=-3 \\
-b \\
c-b\end{array}$ & $\begin{array}{l}5.5 \\
5.2\end{array}$ & $\begin{array}{l}22.7 \\
23.9\end{array}$ & $\begin{array}{l}62.22 \\
68.2\end{array}$ & $\begin{array}{l}11.1 \\
11.2\end{array}$ & $\begin{array}{l}4.13 \\
4.60\end{array}$ & $\begin{array}{l}3.78 E-06 \\
3.56 E-06\end{array}$ & $\begin{array}{r}51.4 \\
58.0\end{array}$ & $\begin{array}{l}3.90 \\
5.03\end{array}$ & $\begin{array}{l}85.0 \\
80.3\end{array}$ & $\begin{array}{l}6.8 \\
6.4\end{array}$ & $\begin{array}{l}0.75 \\
0.81\end{array}$ & $\begin{array}{l}112.9 \\
98.8\end{array}$ & $\begin{array}{l}9.0 \\
7.9\end{array}$ \\
\hline $\begin{array}{c}\mathrm{cur-2} \\
-\mathrm{c} \\
-c \\
-\mathrm{d} \\
-\mathrm{e} \\
\mathrm{cu}-4\end{array}$ & $\begin{array}{l}7.3 \\
6.2 \\
6.7 \\
6.0\end{array}$ & $\begin{array}{l}34.2 \\
42.9 \\
26.3 \\
30.6\end{array}$ & $\begin{array}{l}53.7 \\
49.5 \\
45.2 \\
55.8\end{array}$ & $\begin{array}{l}15.6 \\
16.5 \\
13.1 \\
13.5\end{array}$ & $\begin{array}{l}4.68 \\
6.992 \\
3.993 \\
5.10\end{array}$ & $\begin{array}{l}3.58 E-06 \\
2.47-06 \\
2.25-06 \\
1.52 E-06\end{array}$ & $\begin{array}{l}54.3 \\
44.8 \\
37.1 \\
35.5\end{array}$ & $\begin{array}{l}4.52 \\
2.32 \\
1.45 \\
1.27\end{array}$ & $\begin{array}{l}70.0 \\
50.9 \\
43.6 \\
34.4\end{array}$ & $\begin{array}{l}5.6 \\
4.1 \\
3.5 \\
2.8\end{array}$ & $\begin{array}{l}0.74 \\
0.770 \\
0.06 \\
0.61\end{array}$ & $\begin{array}{l}94.4 \\
73.0 \\
65.7 \\
56.3\end{array}$ & $\begin{array}{l}7.5 \\
5.8 \\
5.3 \\
4.5\end{array}$ \\
\hline $\begin{array}{c}-c \\
-d \\
-d \\
-e \\
B r-1\end{array}$ & $\begin{array}{l}3.0 \\
2.8 \\
3.6\end{array}$ & $\begin{array}{l}17.0 \\
12.5 \\
15.5\end{array}$ & $\begin{array}{l}49.7 \\
50.0 \\
48.3\end{array}$ & $\begin{array}{l}7.2 \\
6.0 \\
7.5\end{array}$ & $\begin{array}{l}5.67 \\
4.46 \\
4.31\end{array}$ & $\begin{array}{l}1.144 E-06 \\
1.325-06 \\
1.74 E-06\end{array}$ & $\begin{array}{l}42.9 \\
47.2 \\
48.3\end{array}$ & $\begin{array}{l}2.11 \\
2.70 \\
2.99\end{array}$ & $\begin{array}{l}39.7 \\
56.8 \\
59.3\end{array}$ & $\begin{array}{l}3.2 \\
4.5 \\
4.7\end{array}$ & $\begin{array}{l}0.72 \\
0.76 \\
0.75\end{array}$ & $\begin{array}{l}55.1 \\
74.6 \\
78.7\end{array}$ & $\begin{array}{l}4.4 \\
6.0 \\
6.3\end{array}$ \\
\hline $\begin{array}{c}c-1 \\
-a \\
-c \\
-d \\
-e \\
0-a\end{array}$ & $\begin{array}{l}3.0 \\
20.1 \\
38.1 \\
3.7\end{array}$ & $\begin{array}{l}12.9 \\
3.4 \\
3.7 \\
7.6\end{array}$ & $\begin{array}{l}21.0 \\
28.0 \\
12.1 \\
0.8\end{array}$ & $\begin{array}{l}6.1 \\
2.1 .0 \\
33.0 \\
5.5\end{array}$ & $\begin{array}{l}4.28 \\
0.17 \\
0.10 \\
2.05\end{array}$ & $\begin{array}{l}2.325 E-06 \\
1.495-05 \\
1.58=-05 \\
3.39 E-06\end{array}$ & $\begin{array}{l}53.0 \\
53.0 \\
52.9 \\
59.7\end{array}$ & $\begin{array}{l}4.13 \\
3.81 \\
3.97 \\
5.65\end{array}$ & $\begin{array}{l}153.9 \\
178.0 \\
175.3 \\
155.8\end{array}$ & $\begin{array}{l}12.3 \\
14.2 \\
14.0 \\
12.5\end{array}$ & $\begin{array}{l}0.69 \\
0.81 \\
0.71 \\
0.80\end{array}$ & $\begin{array}{l}223.0 \\
220.8 \\
228.6 \\
194.5\end{array}$ & $\begin{array}{l}17.8 \\
17.7 \\
19.9 \\
15.6\end{array}$ \\
\hline $\begin{array}{l}\text { Bn-2 } \\
-2 \\
B n-3\end{array}$ & 7.2 & 12.5 & 19.0 & 10.2 & 1.74 & $4.68 E-06$ & 54.1 & 4.09 & 153.7 & 12.3 & 0.76 & 202.4 & 16.2 \\
\hline $\begin{array}{c}-a \\
-b \\
- \\
-e \\
\text { Inom- }\end{array}$ & $\begin{array}{l}1.2 \\
22.3 \\
14.6\end{array}$ & $\begin{array}{l}11.1 \\
6.1 \\
2.4\end{array}$ & $\begin{array}{l}1.9 \\
3.5\end{array}$ & $\begin{array}{l}3.8 \\
23.7 \\
15.2\end{array}$ & $\begin{array}{l}9.25 \\
0.27 \\
0.16\end{array}$ & $\begin{array}{l}1.355-00 \\
1.288-05 \\
9.78 E-06\end{array}$ & $\begin{array}{l}46.0 \\
40.1 \\
60.4\end{array}$ & $\begin{array}{l}2.50 \\
1.82 \\
5.67\end{array}$ & $\begin{array}{l}89.7 \\
138.1 \\
158.0\end{array}$ & $\begin{array}{l}7.2 \\
11.0 \\
12.6\end{array}$ & $\begin{array}{l}0.75 \\
0.700 \\
0.83\end{array}$ & $\begin{array}{l}119.7 \\
196.7 \\
190.4\end{array}$ & $\begin{array}{l}9.6 \\
15.7 \\
15.2\end{array}$ \\
\hline 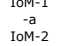 & 1.65 & 7.93 & 26.77 & 3.65 & 4.81 & $1.17 €-06$ & 50.30 & 3.27 & 60.6 & 4.8 & 0.77 & 78.9 & 6.3 \\
\hline $\begin{array}{c}-c \\
-c \\
-d \\
-0 \\
\text { rom-3 }\end{array}$ & $\begin{array}{l}\begin{array}{l}151.00 \\
55.30 \\
11.80\end{array}\end{array}$ & $\begin{array}{l}8.85 \\
12.04 \\
23.34\end{array}$ & $\begin{array}{l}1.23 \\
29.91 \\
6.26\end{array}$ & $\begin{array}{l}153.09 \\
55.28 \\
17.32\end{array}$ & $\begin{array}{l}0.06 \\
0.222 \\
1.98\end{array}$ & $\begin{array}{l}4.800=-05 \\
1.7115-05 \\
5.29 E-06\end{array}$ & $\begin{array}{l}40.89 \\
43.77 \\
45.24\end{array}$ & $\begin{array}{l}1.75 \\
2.20 \\
2.37\end{array}$ & $\begin{array}{l}57.9 \\
54.1 \\
56.3\end{array}$ & $\begin{array}{l}4.6 \\
4.3 \\
4.5\end{array}$ & $\begin{array}{l}0.75 \\
0.75 \\
0.76\end{array}$ & $\begin{array}{l}77.0 \\
772.6 \\
74.5\end{array}$ & $\begin{array}{l}6.2 \\
5.8 \\
6.0\end{array}$ \\
\hline 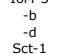 & $\begin{array}{l}16.70 \\
5.00\end{array}$ & 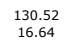 & $\begin{array}{l}59.19 \\
45.56\end{array}$ & $\begin{array}{l}47.67 \\
9.14\end{array}$ & $\begin{array}{l}7.82 \\
3.33\end{array}$ & $\begin{array}{l}1.688 E-05 \\
2.95 E-06\end{array}$ & $\begin{array}{l}61.59 \\
91.66\end{array}$ & $\begin{array}{l}6.16 \\
19.92\end{array}$ & $\begin{array}{l}65.1 \\
60.6\end{array}$ & $\begin{array}{l}5.2 \\
4.9\end{array}$ & $\begin{array}{l}0.83 \\
0.87\end{array}$ & $\begin{array}{l}78.1 \\
69.6\end{array}$ & $\begin{array}{l}6.3 \\
5.6\end{array}$ \\
\hline $\begin{array}{c}-1 \\
-a \\
-b \\
s c-2\end{array}$ & $\begin{array}{l}38.50 \\
26.40\end{array}$ & $\begin{array}{l}40.72 \\
15.56\end{array}$ & $\begin{array}{l}51.51 \\
23.61\end{array}$ & $\begin{array}{l}48.33 \\
30.18\end{array}$ & $\begin{array}{l}1.06 \\
0.59\end{array}$ & $\begin{array}{l}1.195-05 \\
7.10 E-06\end{array}$ & $\begin{array}{l}49.07 \\
43.58\end{array}$ & $\begin{array}{l}3.64 \\
2.32\end{array}$ & $\begin{array}{l}45.7 \\
43.5\end{array}$ & $\begin{array}{l}3.7 \\
3.5\end{array}$ & $\begin{array}{l}0.72 \\
0.69\end{array}$ & $\begin{array}{l}63.7 \\
62.7\end{array}$ & $\begin{array}{l}5.1 \\
5.0\end{array}$ \\
\hline $\begin{array}{c}-c \\
-a \\
-b \\
-c \\
-c\end{array}$ & $\begin{array}{l}3.95 \\
7.10 \\
4.90\end{array}$ & $\begin{array}{l}12.37 \\
9.77 \\
11.23\end{array}$ & $\begin{array}{l}21.51 \\
8.30 \\
7.12\end{array}$ & $\begin{array}{l}6.96 \\
9.44 \\
7.58\end{array}$ & $\begin{array}{l}3.13 \\
1.38 \\
2.29\end{array}$ & $\begin{array}{l}2.121-06 \\
2.06-0.06 \\
1.71 E-06\end{array}$ & $\begin{array}{l}54.35 \\
43.37 \\
37.84\end{array}$ & $\begin{array}{l}4.45 \\
2.38 \\
1.46\end{array}$ & $\begin{array}{r}56.7 \\
40.3 \\
41.6\end{array}$ & $\begin{array}{l}4.5 \\
3.2 \\
3.3\end{array}$ & $\begin{array}{l}0.76 \\
0.73 \\
0.74\end{array}$ & $\begin{array}{l}74.7 \\
55.1 \\
56.4\end{array}$ & $\begin{array}{l}6.0 \\
4.4 \\
4.5\end{array}$ \\
\hline $\begin{array}{l}\text { IAA-2 } \\
\text {-a } \\
\text { IOA-4 }\end{array}$ & 13.70 & 92.66 & 197.38 & 36.46 & 6.76 & $6.25 E-06$ & 55.47 & 4.38 & 32.2 & 2.6 & 0.75 & 42.7 & 3.4 \\
\hline 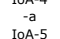 & 7.10 & 60.93 & 132.14 & 22.08 & 8.58 & $3.99 E-06$ & 45.53 & 2.42 & 34.0 & 2.7 & 0.70 & 49.0 & 3.9 \\
\hline $\begin{array}{c}-6 \\
-6 \\
\text { IOA-6 }\end{array}$ & 4.65 & 14.63 & 97.72 & 8.58 & 3.15 & $1.98 \mathrm{E}-06$ & 44.92 & 2.81 & 44.4 & 3.6 & 0.70 & 63.2 & 5.1 \\
\hline $\begin{array}{l}-b \\
-d\end{array}$ & $\begin{array}{l}9.30 \\
6.80\end{array}$ & $\begin{array}{l}47.81 \\
30.39\end{array}$ & $\begin{array}{l}\begin{array}{l}164.21 \\
144.05\end{array}\end{array}$ & $\begin{array}{l}21.36 \\
14.66\end{array}$ & $\begin{array}{l}5.14 \\
4.47\end{array}$ & $\begin{array}{l}5.63 \mathrm{E}=06 \\
2.89 E-06\end{array}$ & $\begin{array}{l}50.29 \\
51.17\end{array}$ & $\begin{array}{l}3.60 \\
3.46\end{array}$ & $\begin{array}{l}49.9 \\
37.7\end{array}$ & $\begin{array}{l}4.0 \\
3.0\end{array}$ & $\begin{array}{l}0.74 \\
0.73\end{array}$ & $\begin{array}{l}67.5 \\
51.7\end{array}$ & $\begin{array}{l}5.4 \\
4.1\end{array}$ \\
\hline
\end{tabular}

